Review

\title{
A Critical-Systematic Review of the Interactions of Biochar with Soils and the Observable Outcomes
}

\author{
Jackson Nkoh Nkoh 1,2,*(D), M. Abdulaha-Al Baquy ${ }^{3, * \mathbb{D}}$, Shamim Mia ${ }^{4, * \mathbb{D}}$, Renyong Shi ${ }^{1,2}$, \\ Muhammad Aqeel Kamran ${ }^{5}$, Khalid Mehmood ${ }^{6}$ and Renkou Xu ${ }^{1,2}$
}

check for

updates

Citation: Nkoh, J.N.; Baquy, M.A.-A.; Mia, S.; Shi, R.; Kamran, M.A.;

Mehmood, K.; Xu, R. A

Critical-Systematic Review of the Interactions of Biochar with Soils and the Observable Outcomes.

Sustainability 2021, 13, 13726. https:/ / doi.org/10.3390/su132413726

Academic Editors: Keiji Jindo and Hans Langeveld

Received: 4 November 2021

Accepted: 10 December 2021

Published: 13 December 2021

Publisher's Note: MDPI stays neutral with regard to jurisdictional claims in published maps and institutional affiliations.

Copyright: (c) 2021 by the authors. Licensee MDPI, Basel, Switzerland. This article is an open access article distributed under the terms and conditions of the Creative Commons Attribution (CC BY) license (https:/ / creativecommons.org/licenses/by/ $4.0 /)$.
1 State Key Laboratory of Soil and Sustainable Agriculture, Institute of Soil Science, Chinese Academy of Sciences, P.O. Box 821, Nanjing 210008, China; ryshi@issas.ac.cn (R.S.); rkxu@issas.ac.cn (R.X.)

2 College of Advanced Agricultural Sciences, University of Chinese Academy of Sciences, Beijing 100049, China

3 Department of Soil Science, Faculty of Agriculture, Hajee Mohammad Danesh Science and Technology University, Dinajpur 5200, Bangladesh

4 Department of Agronomy, Patuakhali Science and Technology University, Dumki 8602, Bangladesh

5 College of Environmental and Resource Sciences, Zhejiang University, Hangzhou 310027, China; kamran2093@yahoo.com

6 Department of Agronomy, Faculty of Agriculture, University of Poonch Rawalakot, Azad Kashmir 12350, Pakistan; khalidmehmoodagro@upr.edu.pk

* Correspondence: nkohjackson@issas.ac.cn (J.N.N.); mabaquy@hstu.ac.bd (M.A.-A.B.); smia_agr@pstu.ac.bd (S.M.); Tel.: +86-131-2172-6308 (J.N.N.)

\begin{abstract}
Biochar research has experienced a significant increase in the recent two decades. It is growing quickly, with hundreds of reviews, including meta-analyses, that have been published reporting diverse effects of biochar on soil properties and plant performance. However, an in-depth synthesis of biochar-soil interactions at the molecular level is not available. For instance, in many meta-analyses, the effects of biochar on soil properties and functions were summarized without focusing on the specificity of the biochar and soil properties. When applied to soils, biochar interacts with different soil components including minerals, organic matter, gases, liquids, and nutrients, while it also changes soil microbial community structure and their occurrence. These different interactions modify soil physicochemical properties with consequences for dynamic changes in nutrient availability and, thus, plant performance. This review systematically analyzed biochar effects on soil properties and functions: (a) soil physical properties; (b) chemical properties; (c) biological properties; and (d) functions (plant performance, nutrient cycling, etc.). Our synthesis revealed that the surface properties of biochar (specific surface area and charge) and its associated nutrient content determine its role in the soil. At the same time, the extent of changes depends on soil properties, suggesting that both biochar and soil properties need to be considered for harvesting benefits of biochar application. Altogether, we believe our synthesis will provide a guide for researchers and practitioners for future research as well as large-scale field applications.
\end{abstract}

Keywords: biochar; soil physicochemical properties; soil aggregate formation; soil aggregate stability; soil fertility; pyrolysis

\section{Introduction}

The soil environment is made up of an interactive ensemble of organic matter (OM), minerals, gases, liquids, and macro/microorganisms. The interactions of these different soil components have a modifying influence on soil physicochemical properties that tend to affect the ability of soil to function as (i) an influencer of the atmosphere via mitigation of greenhouse gas (GHG) emission, (ii) a habitat for macro/microorganisms, (iii) a water reservoir and purifier, and (iv) a medium for plant growth. In this regard, the soil can be categorized as a solid phase: minerals and OM; a solution phase: soil water; and a porous phase: soil atmosphere [1,2]. Among these functions of soil, the most dominant function is to support plant growth. However, due to global climatic change (e.g., temperature and 
rainfall) and intensive cultivations, it is often challenging for the soil to carry out these services. One of the main reasons for the reduced performance of the soil is its low reactive surface which affect the cycling of nutrients.

Different strategies have been employed to increase the service-providing capacity of soils. For instance, the application of OM and, recently, pyrogenic carbon in the form of biochar has been suggested [3-6]. Moreover, other problem-specific management practices (e.g., liming for acid soils and gypsum for saline soils) have also been practiced [7]. Among these amendments, biochar, the product of thermal conversion of biomass to pyrogenic carbon, has been receiving quite some interest due to multiple reasons, including its role in climate change mitigation, improvement of soil OM, and changing soil properties for a long term basis.

Hundreds of reviews have been published focusing on particular aspects of biochar and its effects on soil properties and plant performance. For instance, Natasha et al. [8] focused on the effect of biochar on uptake of trace elements, their toxicity, and detoxification mechanisms in plants. Oni et al. [9] reviewed the application of biochar to soil for remediation and its significance in the economy, while Mandal et al. [10] analyzed the properties of biochar composites and their applications to soils. Other researchers focused on (a) the application of biochar in pollution remediation [11,12], (b) the effect of biochar on soil physicochemical properties [13], and (c) the application of biochar in the management of soil acidity $[14,15]$. However, in many of these reviews, the mechanistic understanding between biochar-induced changes in soil properties and soil functions is not well discussed. We acknowledge that these reviews present different aspects of biochar and set a stage for a mechanistic review that can link these different aspects together. Hence, in this review, we present a critical and systematic discussion on mechanistic understanding of biochar properties and how that properties mediate soil properties and how they relate to soil functions and services.

\section{Data Collection and Synthesis}

For this review, we performed a serial search on the Web of Science (WOS) database with different keywords from July 2020 to July 2021 (Figure 1, see Supplementary materials, Text S2 for reasons why WOS was considered for this study). We searched for research and review articles between 2000 and 2021 with the search options set to all databases and titles. Since our focus was on any article containing the word "biochar", we searched for variations of the word (biochar or bio-char). Some of the searched keywords include (i) biochar or biochar or char, or charcoal, or agrichar, (ii) biochar or bio-char + soil, (iii) biochar or bio-char + fertilizer, (iv) biochar or bio-char + agriculture, (v) biochar or bio-char + phosphate, and (vi) biochar or bio-char + greenhouse gases. The selected publications were further screened for those reporting on the (a) production conditions and chemical properties of biochar, (b) application of biochar to soils, (c) reported negative effects of biochar, (d) application of biochar to mitigate climate change, (e) effect of biochar on soil aggregation, and (f) economic importance of biochar. After all data and selected parameters were arranged as required, the effect of biochar on different soil physicochemical parameters was estimated as the percentage (\%) change between the biochar amended and unamended soils. Figure 1 summarizes the search keywords and research progress with biochar between 2000 and 2021, estimated by the number of publications. 

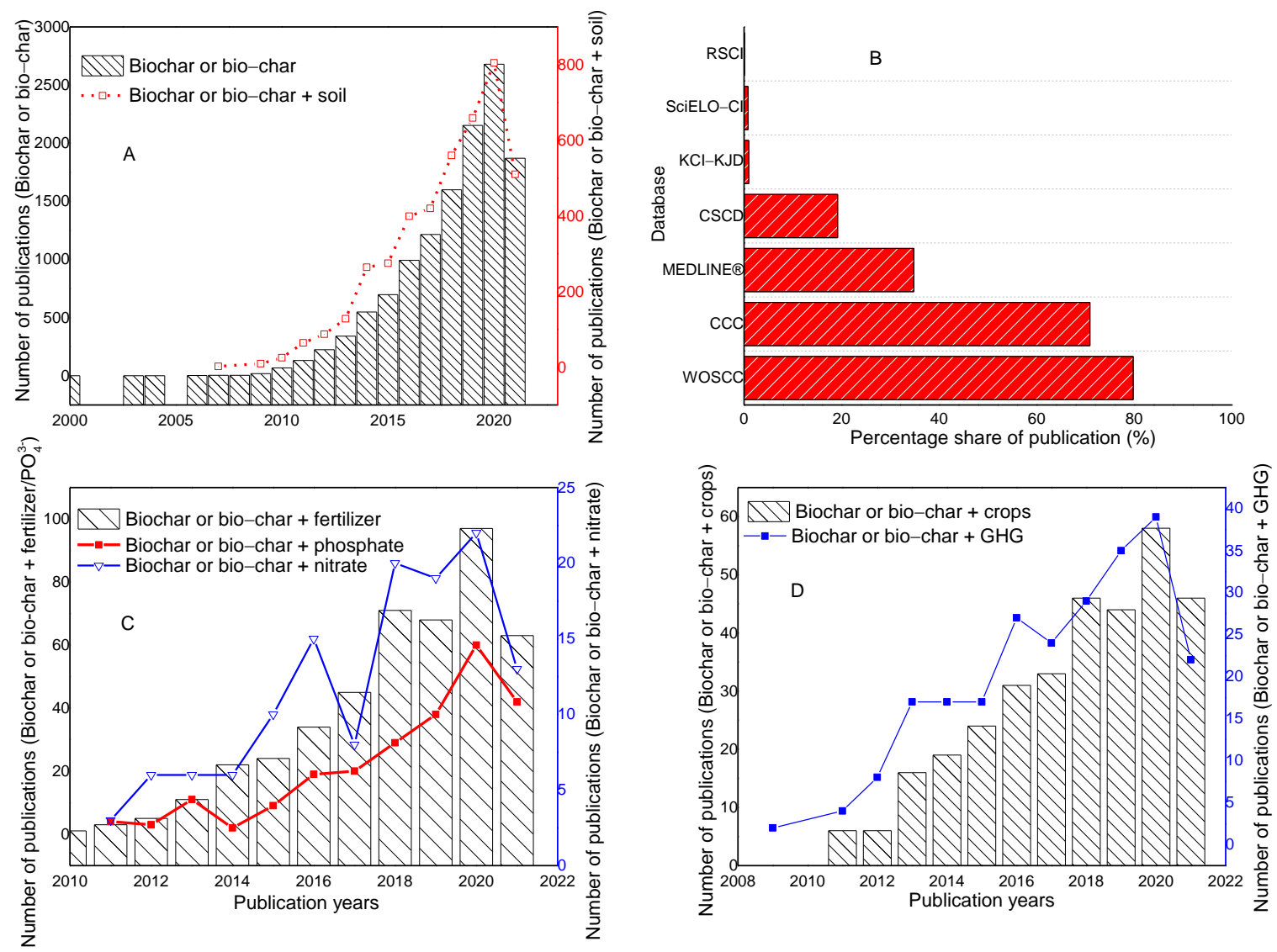

Figure 1. Total number of the publication containing the keywords biochar or bio-char and biochar or bio-char + soil (A), number of publications in different databases (B), biochar or bio-char + phosphate/nitrate (C), and biochar or bio-char + crops/greenhouse gas (GHG) (D). Web of Science Core Collection (WOSCC), Current Contents Connect (CCC), Russian Science Citation Index (RSCI), Chinese Science Citation Database (CSCD), KCI-Korean Journal Database (KJD).

\section{Biochar}

\subsection{Background}

Biochar (or bio-char) is a word derived by combining biomass and charcoal to denote the end product of the thermal conversion of biomass in the presence of limited or no supply of oxygen, a process commonly known as pyrolysis. It is synonymous with char, charcoal, and agrichar, although it is objectively produced for soil application to achieve soil improvements and environmental gains. Biochar can be produced using many different ways from slow to fast pyrolysis, gasification, torrefaction, hydrothermal carbonization, etc., with variable feedstock under diverse conditions (pyrolysis temperature, pressure, and residence time).

When biomass is subjected to different pyrolysis conditions, it experiences different chemical transformations: de-hydroxylation, dehydrogenation, oxidation, de-methylation, and decarboxylation. Consequently, aliphatic $C$ chains of the biomass are converted to aromatic $\mathrm{C}$. In further transformations, the aromatic $\mathrm{C}$ can undergo aromatic condensation to form large aromatic clusters containing fixed $\mathrm{C}$, which can be connected to other units or clusters through aliphatic or aromatic side chains (Figure 2). Like many chemical processes, the chemical transformation of biomass is often accompanied by the production of intermediate products (e.g., volatile C), which could be trapped within the large aromatic clusters. Another important outcome of the biomass transformation process is the production of ash, which is the form in which nutrients in the original biomass are preserved in biochar. Thus, the produced biochar is majorly characterized to have three main contents: fixed C, volatile $C$, and ash. Nevertheless, the extent of these chemical processes is largely controlled by 
the production conditions and feedstock type and the products formed can range from partially charred to highly carbonized materials.

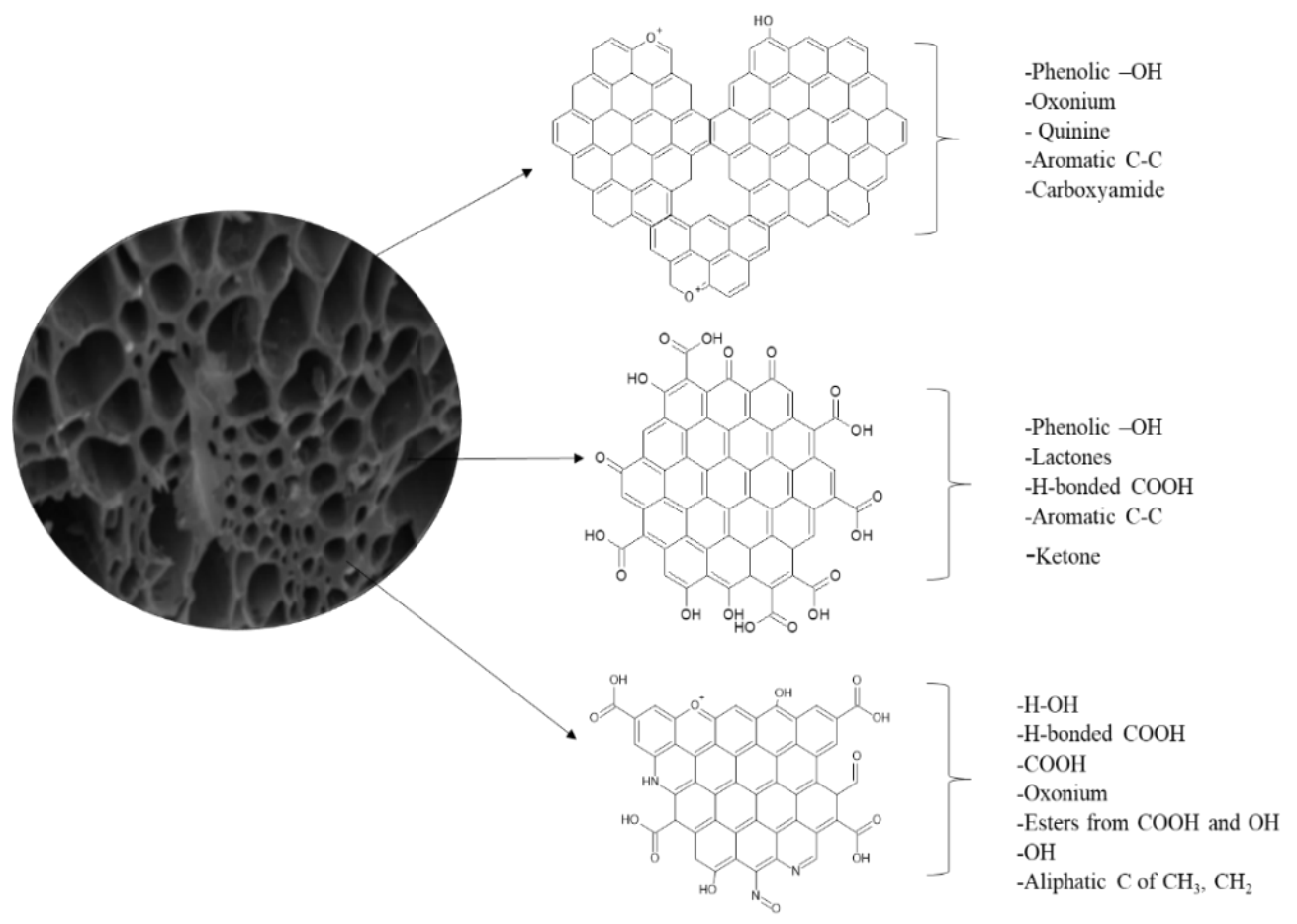

Figure 2. A model biochar structure with different functional groups.

\subsection{Biochar Production Conditions and Selected Physicochemical Properties}

Biochar production rate and its quality (e.g., physicochemical properties) generally depend on biomass source (feedstock), pyrolysis temperature, and pyrolysis duration [16]. Given that there is a large diversity in feedstock and production conditions, the physicochemical properties of biochar are also diverse (Table 1 Panel A, Table S1). Generally, the production rate reduces with the increase of temperature while the relative content of carbon $(\mathrm{C})$ increases, but hydrogen $(\mathrm{H})$ and oxygen $(\mathrm{O})$ content decreases (Figure 2 and Table S1) [17]. These changes occur due to the chemical transformation of aliphatic $C$ to aromatic $\mathrm{C}$. The amount of biochar produced is reduced at higher temperatures, the nutrients in the original biomass concentrate, and thus, the ash content increases. The $\mathrm{pH}$ of biochar is positively associated with pyrolysis temperature due to the (a) production of alkaline compounds, (b) separation of alkali ( $\mathrm{Na}, \mathrm{Mg}, \mathrm{Ca}$, and $\mathrm{K}$ ) salts from organic compounds, and (c) destruction of acidic functional groups [5]. Thus, the increased concentration of base cations in biochar at higher pyrolysis temperature implies that the alkalinity of biochar directly and positively relates to the total equivalent base cations [18].

Aromatic condensation during the transformation of biomass to biochar increases the specific surface area (SSA) of biochar. For example, peanut shell-derived biochar produced at $300{ }^{\circ} \mathrm{C}$ has a surface area of $3.1 \mathrm{~m}^{2} \mathrm{~g}^{-1}$ instead of $448.2 \mathrm{~m}^{2} \mathrm{~g}^{-1}$ when produced at $700{ }^{\circ} \mathrm{C}$ [19]. However, biochar loses its oxygen-containing functional groups during aromatic condensation, suggesting that low-temperature biochar generally carries a negative surface charge (CEC) [20]. On the other hand, water-extractable OM available nutrients, volatile matter content are negatively related to pyrolysis temperature and pyrolysis time [21]. Nevertheless, these relationships depend on the feedstock type, given that different biomasses present different initial carbon matrices. For instance, woody biomass was reported to have larger surface areas than grasses and chicken manure [22]. Moreover, the CEC of canola straw biochar was 199, 210, and $179 \mathrm{cmol}_{+} \mathrm{kg}^{-1}$, while that of maize biochar was 183,304 , and $210 \mathrm{cmol}_{+} \mathrm{kg}^{-1}$ when produced at 300,500 , and $700{ }^{\circ} \mathrm{C}$, respectively [23]. 
Table 1 Panel B (Table S2) shows other properties of biochar such as alkalinity, CEC, exchangeable base cations $\left(\mathrm{Ca}^{2+}, \mathrm{Mg}^{2+}, \mathrm{Na}^{+}\right.$, and $\left.\mathrm{K}^{+}\right)$, and types of functional groups Average across all production conditions, it can be seen that biochar is generally basic while negatively charged functional groups dominate its surfaces. However, biochar may also carry a slightly positive charge if it carries sufficient positively charged functional groups (e.g., oxonium groups). Nevertheless, these surface charges are pH-dependent, suggesting that a single biochar can act as both a positive and negative surface based on the $\mathrm{pH}$ of the medium. Therefore, biochar generally can buffer soil $\mathrm{pH}$ and increase cationic retention in the soil $[5,24,25]$. Altogether, there are trade-offs in obtaining desired properties and therefore, a choice needs to be made for getting a certain combination of properties.

Table 1. The mean values of the pyrolysis temperature and physicochemical characteristics of biochar produced from different feedstock. Panel A reports the mean values of 171 studies (Table S1), while Panel B reports the mean values of 33 studies (Table S2).

\begin{tabular}{|c|c|c|c|c|}
\hline \multicolumn{5}{|c|}{ Panel A: $n=171$} \\
\hline Parameter & Mean & Minimum & Maximum & SD \\
\hline Pyrolysis temperature $\left({ }^{\circ} \mathrm{C}\right)$ & 484.07 & 100 & 900 & 171 \\
\hline $\mathrm{pH}$ & 8.84 & 3.3 & 12.4 & 1.86 \\
\hline Yield (\%) & 41.09 & 21.6 & 99.9 & 17.26 \\
\hline Ash (\%) & 16.99 & 0.1 & 81.7 & 18.70 \\
\hline Surface area $\left(\mathrm{m}^{2} / \mathrm{g}\right)$ & 94.33 & 0.76 & 907.4 & 158 \\
\hline $\mathrm{C}(\%)$ & 62.22 & 7.9 & 94.2 & 19.43 \\
\hline $\mathrm{H}(\%)$ & 3.06 & 0.3 & 25.1 & 2.46 \\
\hline $\mathrm{O}(\%)$ & 17.69 & 1 & 59 & 11.49 \\
\hline $\mathrm{N}(\%)$ & 1.39 & 0.06 & 16.6 & 1.35 \\
\hline \multicolumn{5}{|c|}{ Panel B: $n=33$} \\
\hline Pyrolysis temperature $\left({ }^{\circ} \mathrm{C}\right)$ & 419 & 300 & 700 & 123 \\
\hline $\mathrm{pH}$ & 9.25 & 6.42 & 11.32 & 1.45 \\
\hline Alkalinity $\left(\mathrm{cmol}_{+} \mathrm{kg}^{-1}\right)$ & 199.1 & 79.8 & 326.1 & 76.3 \\
\hline $\mathrm{CEC}\left(\mathrm{cmol}_{+} \mathrm{kg}^{-1}\right)$ & 159.5 & 15 & 304 & 67.4 \\
\hline \multicolumn{5}{|l|}{ Functional groups $\left(\mathrm{cmol} \mathrm{kg}^{-1}\right)$} \\
\hline Phenolic & 99.61 & 26 & 160 & 44.1 \\
\hline Lactonic & 34.18 & 15.6 & 51 & 9.19 \\
\hline Carboxylic & 19.86 & 1.1 & 63.5 & 21.5 \\
\hline $\begin{array}{l}\text { Sum of exchangeable base } \\
\text { cations }\left(\mathrm{cmol}_{\mathrm{c}} \mathrm{kg}^{-1}\right)\end{array}$ & 221.1 & 70.8 & 524 & 115 \\
\hline
\end{tabular}

\subsection{Preparing Designer Biochar}

Production and use of function-specific biochars (e.g., adsorbent of ionic nutrients and contaminants) has been gaining attention and, therefore, engineered biochar production has increased although their large-scale application has not yet been made possible. Biochars can be modified to make their surfaces more/less positive/negative or increase their SSA. This is particularly important because an improvement in these properties has been shown to increase the efficacy of biochar as an adsorbent material. Specifically, oxidation of biochar using different methods (physical, chemical, and biological) are applied for creating negatively charged functional groups (e.g., $\mathrm{COO}^{-}$) that contribute to the CEC development. Among the oxidation methods, chemical oxidation (with nitric acid, hydrogen peroxide, etc.) and biological oxidation have been reported [26-28], and the former has been shown to be more effective while the latter is easier to follow. In contrast, positive biochar properties can also be achieved with the addition of metal salts (e.g., $\mathrm{MgCl}_{2}, \mathrm{AlCl}_{3}, \mathrm{FeCl}_{3}$ ) and nitrogen [29,30] since minerals are impregnated into the biochar matrices [31]. Biocharbased composite materials with function-specific surfaces have also been tailored using amine or clay minerals [32]. 


\section{Biochar Modifies Soil Physicochemical Properties}

\subsection{The Effect of Biochar on Soil Hydraulic Properties and Water Holding Capacity}

Biochar is a porous material and, due to its high porosity, biochar can modify soil porosity and water holding capacity (WHC). This has instigated the use of biochar in agricultural practices to mitigate the adverse effects of drought and improve soil fertility [33,34]. The ability of different biochars to modify soil physical properties is dependent on their high porosity and large surface area. This suggests that biochars with high porosity and surface area may induce the greatest effects on influencing soil physical properties. Nevertheless, porosity and surface area of biochar is largely influenced by the pyrolysis temperature and feedstock type (Table S1); therefore, high-quality feedstock and a median temperature must be selected to ensure a balance between biochar yield and desired characteristics.

Long-term (eight years) field experiments showed that even though biochar failed to improve soil aggregation or aggregate stability, it decreased soil bulk density and increased total soil porosity and macroporosity when applied at a high dose of $9 \mathrm{tha}^{-1} \mathrm{y}^{-1}$ [35]. According to the authors, applying biochar to soils in high doses can significantly improve water retention in soil (including gravitational, capillary, and hygroscopic water) as well as increase plant-available water content $(17.8 \%)$. However, when the biochar dosage was halved, only the plant-available water content increased (10.1\%). When applied to soils, biochar decreases the soil bulk density while improving the porosity [36,37]. By decreasing soil bulk density and increasing porosity, biochar can increase soil hydraulic conductivity and water retention $[35,36]$. Contrary to these results, it was observed that applying finer biochar particles to soils decreased the saturated hydraulic conductivity [38]. Moreover, similar negative effects of biochar on soil saturated hydraulic conductivity were reported for coarse-grain soils $[39,40]$. These differences in the effect of biochar reported may be due to differences in soil types used in each study as well as on the biochar particle size given that finer biochar particles will form smaller pore sizes compared to large particles.

On comparing the effects of switchblade grass (SGB) and hemlock (HB) biochars on the WHC of a loamy sand soil, Yu et al. [41] observed that the WHC was increased by $228 \%$ and $133 \%$ when the soil was treated with $10 \%$ SGB and $\mathrm{HB}$, respectively. According to the authors, the increase in WHC corresponded to $448.7 \%$ and $268.3 \%$ of the weights of SGB and $\mathrm{HB}$, respectively, suggesting that SGB biochar is a better option for amending sandy soils. In a laboratory column experiment, Verheijen et al. [42] observed that amending sandy and sandy loam soils with biochar $(1,5,10$, and $20 \%)$ produced at $620^{\circ} \mathrm{C}$ decreased soil bulk density while increasing the WHC. Importantly, the sandy soil experienced significant changes in bulk density and WHC even at $1 \%$ biochar, whereas the sandy loam soil only showed significant changes when biochar was applied at $5 \%$. Further, the authors reported that the effect of biochar particle size on WHC varied for each soil type and with biochar application rate. At an application rate of $20 \%$, WHC was increased by $53.3 \%$ and $43.1 \%$ (sandy soil) and $62.1 \%$ and $37.1 \%$ (sandy loam soil) for small $(0.05-1.0 \mathrm{~mm}$ ) and large particle $(2.0-4.0 \mathrm{~mm})$ size biochar, respectively [42]. For the same soil, biochar application rate has a significant correlation with soil WHC (Figure S2). Nevertheless, the magnitude of this correlation may differ with biochar type and soil type.

\subsection{Impact of Biochar on Soil pH, Cation Exchange Capacity (CEC), and pH Buffering Capacity ( $p H B C$ )}

Biochar is an alkaline material whose alkalinity depends on the ash content of the feedstock, organic and inorganic alkalis, carbonates, and functional groups [23,24]. According to evidence from 71 studies (Table 2 Panel A, Supplementary Table S4), the effect of biochar on soil $\mathrm{pH}$ varies with soil type, initial soil $\mathrm{pH}$, and biochar application rate. The alkalinity of biochar has a strong correlation with total equivalent base cations $\left(R^{2}=0.84\right)$ [18] and when applied to soils, the alkaline substances in biochar interact with the soil minerals to increase soil $\mathrm{pH}$. Moreover, the functional groups on biochar surface (i.e., CEC) interact with soil active acidity and buffer soil $\mathrm{pH}$ while changing in nutrient dynamics can also counteract against acidification (e.g., retention and uptake of $\mathrm{NH}_{4}{ }^{+}$vs conversation of 
$\mathrm{NH}_{4}{ }^{+}$to $\mathrm{NO}_{3}{ }^{-}$and its leaching). For the same soil, the increment in $\mathrm{pH}$ induced by biochar increases with the application rate. The increase in $\mathrm{pH}$ is more significant for soils with higher initial $\mathrm{pH}$ and biochar with higher alkalinity (Table S3). Shi et al. [6] observed that soils with lower CEC and pHBC are highly sensitive to alkalis inputs and would respond favorably when amended with biochar relative to soils with high CEC and pHBC. Regarding the relationship between soil $\mathrm{pH}$ and biochar's alkalinity and $\mathrm{pH}$, it was reported that biochar's alkalinity, and not $\mathrm{pH}$, makes the most significant contribution $\left(\mathrm{R}^{2}=0.95\right)$ in enhancing soil $\mathrm{pH}[43]$.

Table 2. The effect of biochar application on soil physicochemical (Panel A, Table S3) and exchangeable (Panel B, Table S4) properties.

\begin{tabular}{|c|c|c|c|c|}
\hline \multicolumn{5}{|c|}{ Panel A: $n=71$} \\
\hline Parameter & Mean & Minimum & Maximum & SD \\
\hline Pyrolysis temperature $\left({ }^{\circ} \mathrm{C}\right)$ & 368 & 300 & 400 & 27.6 \\
\hline Soil $\mathrm{pH}$ & 5.61 & 3.99 & 8.40 & 1.06 \\
\hline$\Delta \mathrm{pH}$ due to biochar & 1.12 & 0.01 & 3.44 & 0.79 \\
\hline CEC $\left(\mathrm{mmol} \mathrm{kg}^{-1}\right)$ & 91.5 & 51.5 & 177.2 & 27.3 \\
\hline$\%$ increase in CEC due to biochar & 18.6 & -17.2 & 82.8 & 21.0 \\
\hline pHBC $\left(\mathrm{mmol} \mathrm{kg}^{-1} \mathrm{pH}^{-1}\right)$ & 26.0 & 12.0 & 41.7 & 7.60 \\
\hline$\%$ increase in $\mathrm{pHBC}$ due to biochar & 52.0 & 1.02 & 198.5 & 45.0 \\
\hline \multicolumn{5}{|c|}{ Panel B: $n=54$} \\
\hline Soil pH & 4.81 & 3.99 & 5.97 & 0.44 \\
\hline$\Delta \mathrm{pH}$ due to biochar & 0.57 & 0.01 & 1.53 & 0.37 \\
\hline Exchangeable acidity $\left(\mathrm{mmol}_{+} \mathrm{kg}^{-1}\right)$ & 30.9 & 0.9 & 70.2 & 17.2 \\
\hline$\%$ decrease in exchangeable acidity due to biochar & 49.2 & 8.57 & 96.6 & 24.5 \\
\hline Exchangeable $\mathrm{Al}\left(\mathrm{mmol}_{+} \mathrm{kg}^{-1}\right)$ & 29.2 & 0.9 & 67.7 & 16.7 \\
\hline$\%$ decrease in exchangeable $\mathrm{Al}$ due to biochar & 48.5 & 0.7 & 96.5 & 25.1 \\
\hline Exchangeable base cations $\left(\mathrm{mmol}_{+} \mathrm{kg}^{-1}\right)$ & 64.8 & 8.8 & 118.6 & 25.7 \\
\hline $\begin{array}{c}\% \text { increase in exchangeable base cations due to } \\
\text { biochar }\end{array}$ & 95.0 & 16.2 & 243.5 & 57.3 \\
\hline
\end{tabular}

The CEC is a measure of a soil's ability to retain nutrients $\left(\mathrm{H}^{+}, \mathrm{Ca}^{2+}, \mathrm{Mg}^{2+}, \mathrm{Na}^{+}\right.$, or $\mathrm{NH}_{4}^{+}$), and it plays the important role of highlighting how fertile soils are [44]. The Ocontaining functional groups on biochar surface can deprotonate/protonate at different $\mathrm{pH}$ values, thereby making their surface charge characteristics $\mathrm{pH}$-dependent, which becomes progressively negative with increasing $\mathrm{pH}[43,45,46]$. After amending soils with biochar, the CEC of the soils is enhanced given that functional groups of biochar are added to the soil reactive surfaces $[5,25,47]$. However, the extent of change in soil CEC depends on the relative contribution of biochar (CEC of biochar and its application rates), with an estimated increase of up to $82.8 \%$ (applied at $5 \%$ ) (Table 2 and Supplementary Table S3). In contrast, negative effects of $-17.2 \%$ (applied at $1 \%$ ) have also been reported (Tables 2 and S3).

Soil pHBC measures how much acid or alkali is required to decrease or increase the $\mathrm{pH}$ of soil by one unit [25]. After amending soils with biochar, the exchangeability of the soil was enhanced, given that biochar has abundant anionic functional groups (e.g., $\mathrm{COO}^{-}$) and cation exchange sites to accommodate $\mathrm{H}^{+}[5,25,47]$. Importantly, the ability of biochar to enhance the soil exchange capacity is a direct result of its enhancing effect on soil CEC. As shown in Table S3, the effect of biochar on soil CEC and pHBC increases with biochar application rate, and the greater its effect on CEC, the greater is its effect on pHBC. Specifically, at application rates of $3 \%$ and $5 \%$, peanut straw biochar increased the CEC of Ultisol derived from granite by $47.2 \%$ and $82.8 \%$ while increasing its $\mathrm{pHBC}$ by $65.8 \%$ and $123.2 \%$, respectively. Similarly, at the same rates and for an Oxisol from basalt, the same biochar increased the CEC by $34.2 \%$ and $51.3 \%$, while the pHBC was increased by $46.3 \%$ and $92.0 \%$, respectively (Table S3) [25]. 
Attenuated total reflectance (ATR)-FTIR spectroscopic analysis revealed that biochar's enhancing effect on $\mathrm{pHBC}$ is dominated by the protonation of carboxylate groups on the biochar's surface (Biochar- $\mathrm{COO}^{-}+\mathrm{H}^{+} \rightleftharpoons$ Biochar- $\mathrm{COOH}$ ) and the decrease in soil effective CEC (ECEC) during acidification $[5,47]$. The curated data show that biochars with higher alkalinity and functional groups (Table S2) tend to significantly enhance soil CEC and, consequently, pHBC compared to those with lower alkalinity and functional groups, and the trend was similar for different soils (Table S3). A plot of the \% increase in CEC against the \% increase in pHBC due to biochar addition (Figure 3) shows a significant linear correlation $\left(R^{2}=0.7241\right)$ and supports the inference that the enhancing effect of biochar on $\mathrm{pHBC}$ is a consequence of its enhancing effect on soil CEC.

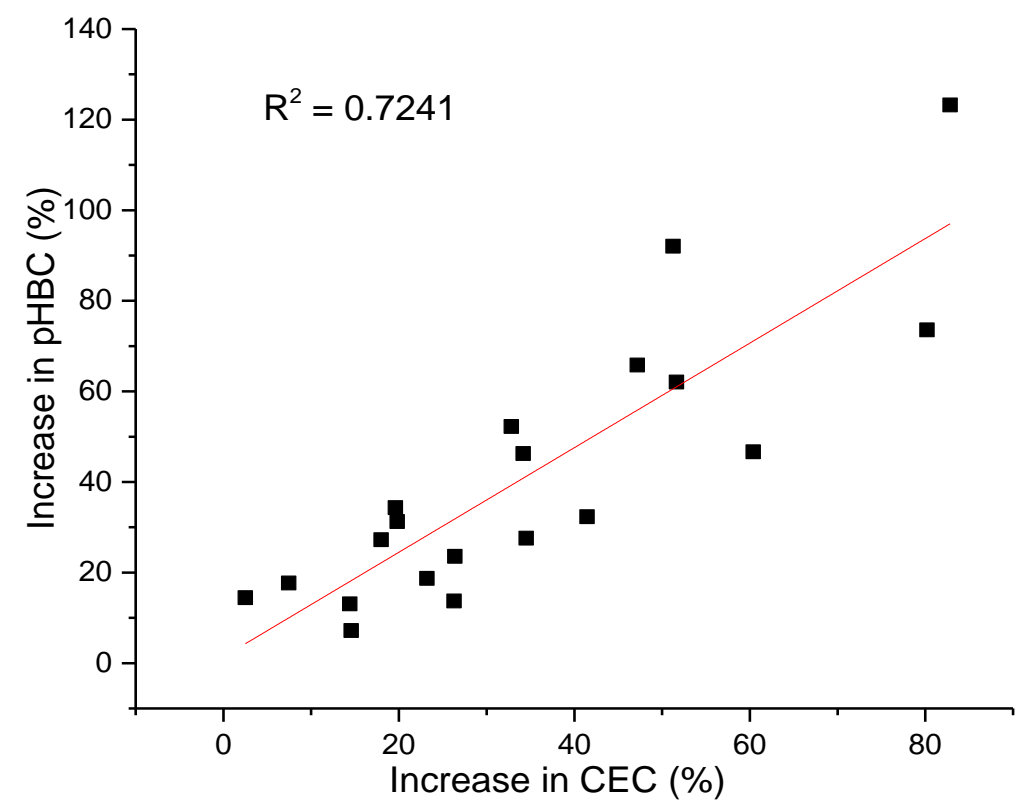

Figure 3. The relationship between the \% increase in soil pHBC and CEC as influenced by biochar addition at various rates $(n=20)$. The complete data is given in Table S3 and curated from the literature $[6,25]$.

\subsection{Impact of Biochar on Soil Exchangeable Properties}

When incorporated into soils, biochar tends to modify the physicochemical properties of soils, including their exchangeable properties. Of these exchangeable properties, the exchangeable acidity $\left(\mathrm{Al}^{3+}+\mathrm{H}^{+}\right)$is of particular concern given that a significant portion $(\sim 96-100 \%)$ of it is made up of the phytotoxic exchangeable $\mathrm{Al}^{3+}$ (Table 2 Panel B, Supplementary Table S4). The high alkalinity of biochar improves soil $\mathrm{pH}$ and consequently decreases exchangeable acidity, and the effect depends on the biochar feedstock, application rate, and alkalinity. For the same biochar and the same soil type, the decrease in exchangeable acidity increases with the biochar application rate (Table S4). The relationship between an increase in soil $\mathrm{pH}$ and a \% decrease in soil exchangeable acidity induced by biochar (Figure 4a) shows a significant correlation $\left(R^{2}=0.6065\right)$ and suggests that enhancing soil $\mathrm{pH}$ is the dominant mechanism through which biochar reduces soil exchangeable acidity.

The alkaline nature of biochar results in soils with high $\mathrm{pH}$ and low exchangeable acidity. Because biochar decreases exchangeable acidity by enhancing soil $\mathrm{pH}$, it is expected that exchangeable $\mathrm{Al}^{3+}$ should be affected in the same way since it is the major component of exchangeable acidity. However, the correlation between an increase in $\mathrm{pH}$ and a \% decrease in exchangeable $\mathrm{Al}^{3+}$ (Figure $4 \mathrm{~b}$ ) shows that this mechanism is only responsible for about $51.7 \%$ reduction in the exchangeable $\mathrm{Al}^{3+}\left(\mathrm{R}^{2}=0.5171\right)$. Nevertheless, the relationship between $\%$ decrease in exchangeable $\mathrm{Al}^{3+}$ and $\%$ decrease in soil exchangeable acidity (Figure $4 \mathrm{c}$ ) suggests that the decrease in exchangeable $\mathrm{Al}^{3+}$ is predominantly due 
to the decrease in exchangeable acidity $\left(R^{2}=0.9623\right)$ induced by biochar and not a direct consequence of an increase in soil $\mathrm{pH}$.
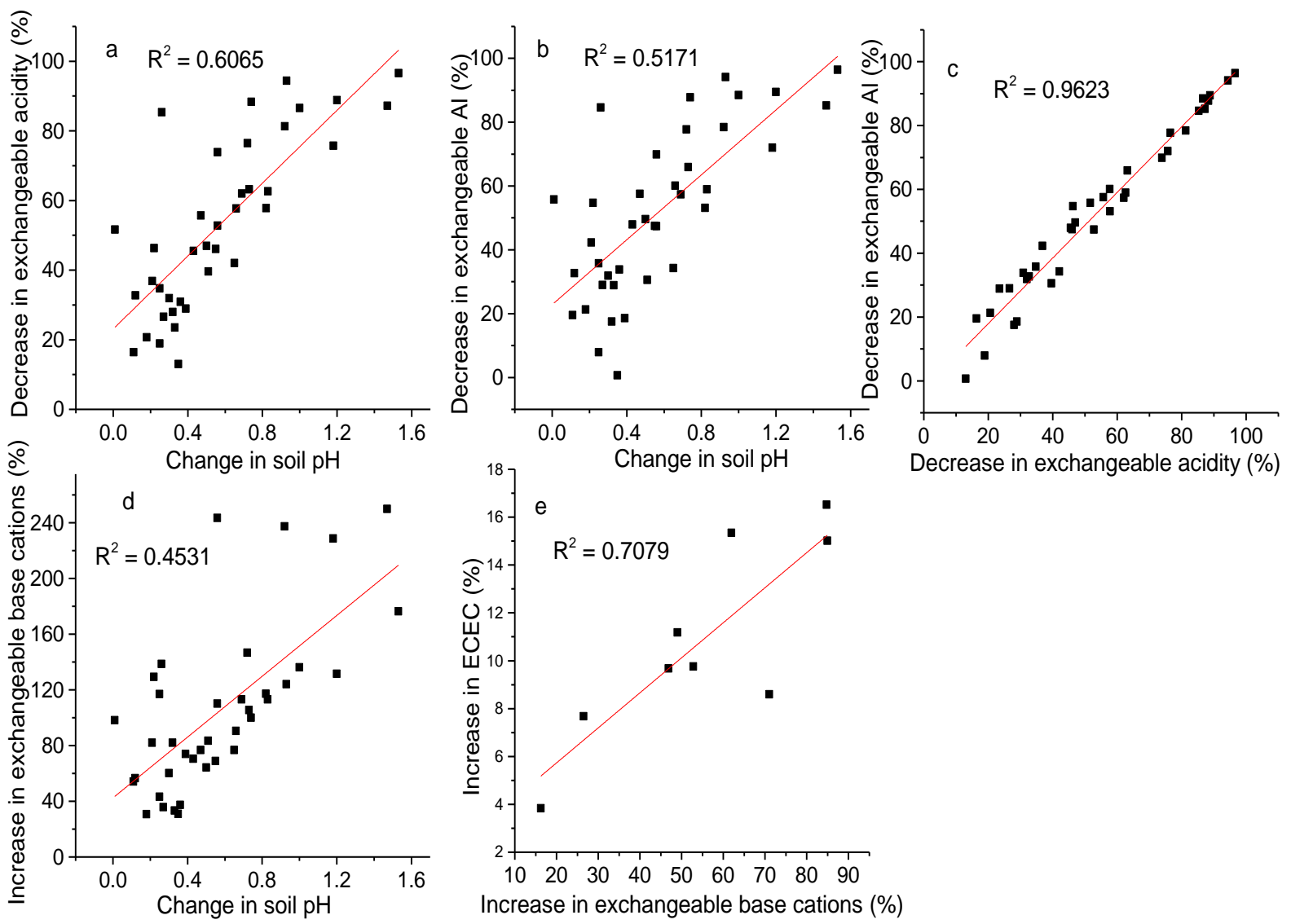

Figure 4. The relationship between a decrease in exchangeable acidity (a), exchangeable $\mathrm{Al}(\mathbf{b})$ and soil $\mathrm{pH}(\mathrm{n}=38)$, decrease in exchangeable acidity and exchangeable $\mathrm{Al}(\mathbf{c})$, exchangeable base cations $\left(\mathrm{Ca}^{2+}+\mathrm{Mg}^{2+}+\mathrm{K}^{+}+\mathrm{Na}^{+}\right)$and soil $\mathrm{pH}((\mathbf{d})$, $\mathrm{n}=38)$, and effective cation exchange capacity (ECEC) and exchangeable base cations $((\mathbf{e}), \mathrm{n}=9)$ as induced by biochar. The complete data is presented in Table S4.

It is true that by enhancing soil $\mathrm{pH}$, biochar promotes the hydrolysis of free $\mathrm{Al}^{3+}$ (to $\mathrm{Al}(\mathrm{OH})_{3}, \mathrm{Al}(\mathrm{OH})_{4}{ }^{-}$, etc.) [6,48]. During this process, some of the $\mathrm{Al}^{3+}$ can also be re-adsorbed onto the soil-biochar surface functional groups (e.g., $\mathrm{COO}-\mathrm{Al}^{2+},-\mathrm{O}-\mathrm{Al}^{2+}$ ) to form part of the $\mathrm{Al}$ bound to soil organic matter (SOM). Thus, this fraction of sorbed exchangeable $\mathrm{Al}^{3+}$ will not be accounted for by the increase in soil $\mathrm{pH}$ caused by biochar. By this reasoning, the relationship between soil $\mathrm{pH}$ and exchangeable $\mathrm{Al}^{3+}$ as induced by biochar will always underestimate the content of $\mathrm{Al}^{3+}$ compared to the relationship between exchangeable acidity and $\mathrm{Al}^{3+}$. Therefore, it is recommended that soil exchangeable $\mathrm{Al}^{3+}$ against exchangeable acidity plots be used and not against $\mathrm{pH}$ to estimate the effectiveness of soil amendment materials in alleviating $\mathrm{Al}$ toxicity in acidic soils.

Biochar contains significant amounts of exchangeable base cations $\left(\mathrm{Ca}^{2+}, \mathrm{Mg}^{2+}, \mathrm{K}^{+}\right.$, and $\mathrm{Na}^{+}$) (Table S2) that can be exchanged for $\mathrm{Al}^{3+}$ and $\mathrm{H}^{+}$when biochar is incorporated into soils. This implies that adding biochars to soils enriches nutrient cations, and the effect depends on the quantity of base cations in pristine biochar (Table S4) [4]. The relationship between exchangeable base cations and soil $\mathrm{pH}$ (Figure $4 \mathrm{~d}$ ) shows that $\mathrm{pH}$ change does not significantly $\left(R^{2}=0.4531\right)$ affect the discharge of base cations from the exchange sites of biochar but, rather, it depends more on the change in effective CEC $\left(E C E C, R^{2}=0.7079\right)$ (Figure 4e). This indicates that when biochar is added to soils, it increases the CEC and the overall surface negative charge, resulting in the discharge of base cations to balance the negative charge [43,47]. 


\subsection{Impact of Biochar on Soil Zeta Potential}

Several studies have reported on the enhancing effects of different biochars on soil CEC and ECEC. While CEC is the quantitative representation of soil negative charge at $\mathrm{pH} 7.0$, the ECEC represents soil negative charge at field conditions or a given $\mathrm{pH}$. Due to the complexity involved in determining both CEC and ECEC, soil scientists often evaluate soil surface charge characteristics using zeta potential measurements. The zeta potential value and sign give an idea of the charge state of a surface and represent the potential in the sliding planes of colloidal particles. The high $\mathrm{pH}$ of biochar renders its surface naturally negative due to the deprotonation of carboxylic acid functional groups on its surface $\left(-\mathrm{COOH}\right.$ to $\left.-\mathrm{COO}^{-}\right)[46,49]$, which takes part in the chemical interaction between biochar particles and soil colloids.

An important view of soil-biochar interaction is that it involves both chemical (chemical bonding) and physical interactions (e.g., electrostatic). The physical aspect of soilbiochar interaction can be estimated when exchangeable base cations $\left(\mathrm{Ca}^{2+}, \mathrm{Mg}^{2+}, \mathrm{Na}^{+}\right.$, $\mathrm{K}^{+}$) and exchangeable acidity $\left(\mathrm{Al}^{3+}\right.$ and $\left.\mathrm{H}^{+}\right)$are released into soil solutions to form the basis for determining soil CEC. Given that the extracted exchangeable base cations and exchangeable acidity are located in the diffuse layer of an electrical double layer of soil colloids, they are considered electrostatically bonded to soil-biochar composites and can therefore not alter the overall charge behavior of soil-biochar composites [43,47]. Contrary to this, the interactions between biochar functional groups (e.g., $-\mathrm{COO}^{-}$) and soil minerals (e.g., $\mathrm{Fe} / \mathrm{Al}$ oxides) occur via chemical bonding (specific adsorption) to form composites with bonds of the form biochar-carboxyl-iron/aluminum-soil (biochar-CO-O-Fe/Al-soil). This kind of specific adsorption can be estimated by evaluating the changes in colloidal surface charge characteristics given that the adsorbed molecule (e.g., $-\mathrm{COO}^{-}$) has to migrate to the Stern layer of the electrical double layers to form chemical bonds [50]. When this occurs, the negative charge of biochar is transferred to soil-biochar composites to alter the surface charge characteristic of the soil. Hence, zeta potential measurements have shown an increase in the negative zeta potentials of different soils treated with biochar, and the magnitude of zeta potential change was proportional to biochar application rates and content of biochar functional groups [43,45,46,49].

\section{The Influence of Biochar on Soil Aggregation}

\subsection{The Role of Biochar in Soil Aggregate Formation}

Soil aggregates are soil clumps whose sizes vary from micro $(<0.25 \mathrm{~mm})$ to macroaggregates $(<0.25$ to $>0.25 \mathrm{~mm}$ in diameter). A soil aggregate is formed through the binding of soil particles with cementing agents released by soil microorganisms, and it has been shown to significantly influence soil functions, including nutrient availability, water, and air movement, and soil fertility [1]. The formation of soil aggregates occurs with complex dynamic interactions of soil minerals, soil particle size (i.e., texture), inorganic binding agents (e.g., $\mathrm{Mg}$, oxyhydroxides), biological binding agents (e.g., soil organic carbon, glomalin-related soil protein, microbial biomass carbon), and biological activities [51]. These aggregates often form different shapes (e.g., granular, platy, and blocky) and create pore spaces that facilitate the movement of air and water needed for healthy plant growth. The SOM greatly regulates the formation of soil structure and the addition of biochar to soils changes soil carbon sequestration by changing SOM stabilization through organo-mineral complexation [13,52].

Being a diverse material, biochar can have variable effects on soil physical properties, including aggregate formation and stability $[53,54]$. The ability of biochar to modify the physical and chemical properties of soils is important for amending highly weathered soils and retarding soil degradation associated with erosion [53]. Nevertheless, the ability of biochar to promote aggregation is largely influenced by biochar feedstock, biochar production condition, and soil type $[55,56]$. This means that while biochar can favor aggregate formation in some soils, it can inhibit its formation in others. For instance, Blanco-Canqui [57] reported a $-15-226 \%$ change in soil aggregate formation using data 
of 34 soils (Figure S1). Their result suggests that biochar could have variable effects on soil aggregation and stability and may only be resolved with a proper mechanistic understanding of the interactions between biochar and soil.

Biochar can enhance soil aggregation in multiple ways. Firstly, biochar interacts with the reactive surfaces of soil minerals through ligand exchange, electrostatic, $\pi-\pi$, and hydrophobic interactions which results in biochar-mineral-OM complexes (microaggregates) [58] (Figure 5a). Therefore, biochars with larger amounts of O-containing functional groups would accelerate the aggregation process faster than biochars with larger $\mathrm{H}$ content. These results suggest that biochar produced at low temperature and biochar that has sufficiently aged could be more effective in promoting aggregation due to their large content of O-containing functional groups $[59,60]$. Secondly, biochar contains abundant base cations (e.g., $\mathrm{Ca}, \mathrm{Mg}$ ) that can bridge the binding of negatively charged minerals together by getting adsorbed in the mineral surfaces; a process known as "flocculation" [61]. Thirdly, the addition of biochar to soils improves soil organic carbon (SOC), and the SOC indirectly influences aggregation by enhancing the contents of biological binding agents [58].

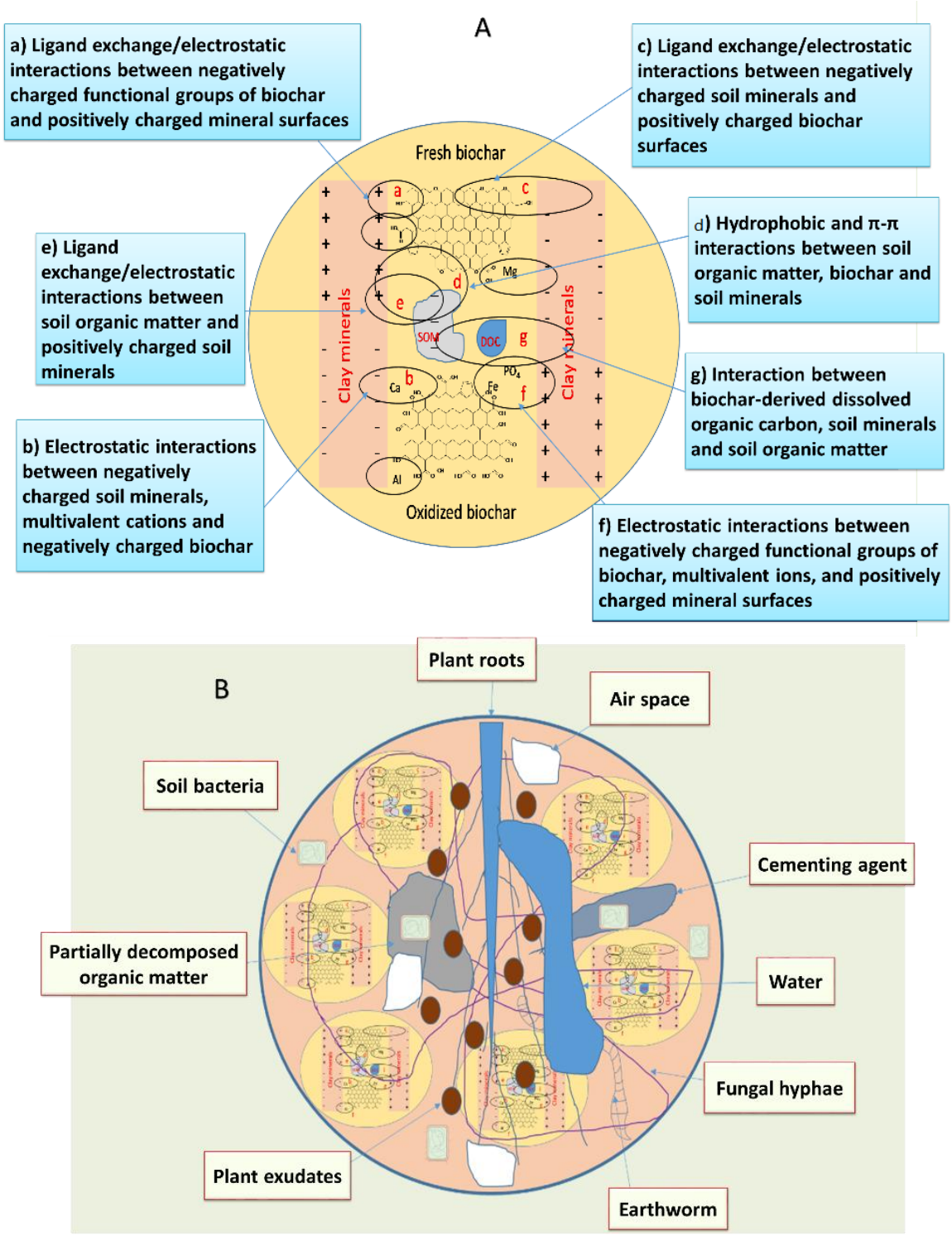

Figure 5. Schematic diagram of the soil micro-aggregate (A) and macro-aggregate (B) stability mechanisms by the biochar. 
The formation of micro and macro-aggregates and their degradation in the soil is dynamic. It is hypothesized in this area of study by one school of thought that macroaggregates are formed from micro-aggregates while in another school of thought, the opposite presumption is considered [62,63]. Without getting insights into the detailed mechanisms, we considered the first hypothesis for our discussion. Once the microaggregates are formed and biochar is applied to soils, it helps to create macro-aggregates by increasing microbial population (e.g., fungal hyphae, bacterial biomass) along with the plant-derived OM addition [64,65] (Figure 5b). Moreover, biochar is hydrophobic and can bring particles together to form aggregates, while its large surface area facilitates interactions between soil components. Thus, through these mechanisms, biochar increased macro-aggregation ( $>250 \mu \mathrm{m})$ by $25 \%$ while the micro-aggregates reduced by $7.1 \%$ [52].

\subsection{The Effect of Biochar on Soil Aggregate Stability}

The stability of soil aggregates in water is controlled mainly by internal soil forces such as van der Waals attraction, hydration, and electrostatic forces [66]. Biochar can change soil aggregate stability by altering (i) the interaction forces, (ii) the chemical interactions between its components with soil aggregates, (iii) the surface charge characteristics, (iv) the SSA and mineral addition, and (v) the microbial community dynamics [66,67]. The underlying mechanisms attributed to this increased stability are the strong interaction of biochar particles with soil minerals or microbes and an increase in electrolyte concentration. The stability of soil aggregates after biochar amendments was found to be variable. For instance, Sun and Lu [68] reported increased stability of soil aggregates after biochar application in clay-rich soil. Further, Pituello et al. [69] observed that the application of biochar to soils improves aggregate stability and soil physical fertility, with the effect being dominant for soils with a coarse texture and smaller content of organic carbon. Similar results were also reported for a range of biochars and soils [51].

Zhang et al. [70] observed in a one-year study that, irrespective of application rate, biochar addition to soils did not significantly alter soil aggregation and stability even though the SOC was improved. In a field experiment, Zhou et al. [35] studied the effect of corn cob-derived biochar on soil aggregation and aggregate stability by applying biochar at rates of 4.5 and $9 \mathrm{tha}^{-1}$ year $^{-1}$. After eight years of application, biochar did not significantly affect soil aggregation or aggregate stability. In a recent study, Burgeon et al. [60] demonstrated that soil receiving fire-derived pyrogenic carbon contained more macro-aggregates than the reference soils. This suggests that pyrogenic carbon facilitated the formation of macro-aggregates through binding soils constituents and micro-aggregates together. Therefore, chemical interactions between larger size biochar, after ageing and carrying more functional groups, can form aggregates with greater stability [27]. However, the role of these diverse biochars could also depend on soil properties, including mineral composition, texture, $\mathrm{pH}$, and initial SOM.

\section{Effect of Biochar Application on Soil Biological Properties}

After soil application, biochars change on soil physicochemical properties, which tend to alter the abundance of soil microbial communities [71,72]. For instance, the application of biochar enhanced soil $\mathrm{pH}$ and increased the content of $\mathrm{NH}_{4}{ }^{+}$, thereby facilitating the activities of ammonia oxidizers [73]. Amending acidic soils with biochars of rice and peanut straws increased soil $\mathrm{pH}$ and the abundance of ammonia-oxidizing archaea but decreased that of ammonia-oxidizing bacteria, thus, inhibiting nitrification during fertilization with urea [74]. In soils contaminated with polycyclic aromatic hydrocarbons (PAHs), using biochar for remediation has proven effective in maintaining microbial diversity [75]. The authors observed that the toxicity and bioavailability of the pollutants were significantly reduced while the growth of rare bacterial genera was enhanced. Kim et al. [76] observed that biochar application to soils increased the diversity of terra preta by up to $25 \%$ while $\mathrm{Xu}$ et al. [77] observed a significant increase in the abundance of $\alpha$-diversity when an acidic soil ( $\mathrm{pH} 4.48$ ) was amended with biochar. According to Chen et al. [78], the effect 
of biochar amendment on microbial community structure varied for different paddy soils. For instance, when paddy soil from Jiangxi province in China was amended with biochar at rates of $20 / 40 \mathrm{tha}^{-1}$, the relative abundances of Betaproteobacteria and Deltaproteobacteria were increased by 54\%/80\% and $164 \% / 151 \%$, respectively. Contrarily, a paddy soil from Sichuan province amended with similar biochar (at same rates) demonstrated a decrease in the abundance of Betaproteobacteria by $46 \% / 52 \%$ while it increased that of Chloroflexi by $27 \% / 61 \%$ [78].

The common practice of disposing of industrial and municipal waste through landfills has potential adverse effects on soil microbial life. In their study, Lu et al. [79] demonstrated that long-term biochar amendment (three years) in the topsoil of a subtropical landfill cover enriched the abundance of Proteobacteria and Acidobacteria but not that of Proteobacteria and Acidobacteria. According to the authors, biochar-amended soils had a decreased abundance of functional genes associated with $\mathrm{C} / \mathrm{N}$ cycling while those associated with $\mathrm{P}$ cycling increased. Nevertheless, the effect of biochar amendment on soil microbial community composition varies with biochar feedstock [80]. In their study, Yu et al. [72] showed that after amending an Oxisol and Mollisol with biochar, soil type was the predominant determining factor of microbial community composition during the initial stages of the experiment and followed by the cropping system. Moreover, it was suggested that biochar mineralization may be a biological process, and accordingly, biochar $C$ availability and large surface area were the main factors influencing microbial colonization [81].

\section{Implications of Biochar Interactions with Soils for Agricultural Productivity}

The physicochemical properties of soils are important parameters that enable soil scientists to understand how soils change over time. Soil properties such as pH, CEC, and anion exchange capacity play important roles in evaluating the health and fertility of soils [82]. When altered, these parameters can be used as indicators for deciding what treatment is required for what soil. The sole application of biochar to soil is sometimes not sufficient to supply the required amount of essential nutrients to plants. The application of biochar along with vermicompost or compost has been suggested to enhance soil fertility and productivity [83]. On the other hand, quick decomposition of organic materials promotes nutrient loss and may pose serious problems on nutrient pollution in aquatic ecosystems. Thus, co-application of compost and biochar is proposed as an option to reduce potential environmental risks [84]. Figure S3 depicts the generalized effect of biochar on nutrient dynamics, management of soil acidification, changes in crop performance, and immobilization of pollutants, and will guide our discussion in this section.

\subsection{Management of Acid Soils}

Acid soils are characterized by low $\mathrm{pH}$, low $\mathrm{CEC}$, and low $\mathrm{pHBC}$. These soils are prone to Al toxicity which inhibits crop growth [85-87]. Since acid soils are easily re-acidified after mineral lime application, biochar is a better alternative amendment material for correcting soil acidity due to its high alkalinity and long-lasting effect on soils [15,24]. Carbonates and surface organic functional groups are the predominant alkaline substances in biochars. When biochars are applied to acid soils, carbonates neutralize the soil acidity while organic functional groups combine with $\mathrm{H}^{+}$and $\mathrm{Al}^{3+}$ [5]. Therefore, the application of biochars to these soils increased their $\mathrm{pH}$, decreased the exchangeable acidity $\left(\mathrm{Al}^{3+}+\mathrm{H}^{+}\right)$, and improved the content of nutrient elements (See Supplementary Text S2, Tables S3 and S5). Adding biochar to soils enhances their exchange ability and in a laboratory study, Shi et al. [85] showed that biochar promoted root elongation in maize plants by inhibiting Al toxicity. In a four-year field experiment, it was observed that biochars significantly increased canola seed and straw yield from four crops due to their ameliorating effect on soil acidity and Al toxicity [86]. From a global-scale meta-analysis, biochar elicited a $25 \%$ average crop yield increment in the tropics, with little effect in the temperate zones [88]. This observation is reasonable given that most soils in the tropics are acidic compared to temperate zones, and when added to acidic soils, biochars can exchange intrinsic nutrient 
cations (e.g., $\mathrm{Ca}^{2+}, \mathrm{Mg}^{2+}, \mathrm{K}^{+}$) for $\mathrm{H}^{+}$in these soils. This results in an increase in soil $\mathrm{pH}$ and bioavailable nutrients required for crop growth.

\subsection{Management of Alkaline Soils}

Given the high intrinsic $\mathrm{pH}$ and alkalinity of biochar, it is not commonly used in alkaline soils ( $\mathrm{pH} \geq 7.4)$ since it may negatively affect the quality of the soil [89]. In combination with NPK fertilizer, biochar application to alkaline soils could be a viable strategy to decrease soil $\mathrm{pH}$ and maintain a high nutrient level [90]. The high nutrient level played an important role in improving seed yield and total biomass of soybean grown on alkaline soils. Even though biochar negatively affected soil bulk density, its application to alkaline soil significantly improved soil CEC, nitrate retention, OC, and bioavailable K [91]. Negatively, because of adsorption onto the surface of biochar, the addition of biochar to alkaline soils resulted in reduced levels of ammonium and phosphate [92,93]. The authors suggested that strong adsorption of $\mathrm{P}$ to the soil-biochar complex was responsible for this decrease given that the desorption of $\mathrm{P}$ pre-adsorbed to $\mathrm{Al} / \mathrm{Fe}$-biochar composites was slow. Nevertheless, it is recommended that acidified biochar be used for application in alkaline soils since it contains a significant amount of oxygen-containing functional groups and nutrients required for plant growth [94]. The use of nutrient-doped or nutrient-laden biochar-based fertilizers to improve the quality of alkaline soils is fast becoming popular. For instance, Elkhlifi et al. [95] and Wu et al. [96] observed that P-laden lanthanum-based biochar and iron-modified biochar improved soil $\mathrm{P}$ availability when applied to alkaline soils, respectively. The versatility of biochar-pristine or modified-makes it a suitable material for amending all kinds of soils, and when composted, important plant nutrients such as N, P, and K were significantly increased in alkaline soils [97].

\subsection{Management of Saline Soils}

Salinization is of growing concern, given that plant growth becomes suppressed due to osmotic imbalances and oxidative stress [98]. The management of saline soils with appropriate rates of biochar has a mitigating effect on $\mathrm{N}$ leaching due to enhanced retention and reduced volatilization of ammonia [99]. The ability of biochar to modify soil physicochemical properties plays an important role in microbial colonization. This has demonstrated positive effects on the abundance of ammonia-oxidizing microorganisms in alkaline soils and the decrease of $\mathrm{N}$ leaching [100]. In their study, Cui et al. [101] showed that a combined application of biochar with effective microorganisms decreased the impact of saline stress on the growth of $S$. cannabin by improving soil fertility and nutrient content. The increasing interest in the co-application of biochar and microorganisms for plant growth stems from the fact that biochar modifies soil physicochemical properties to improve colonization by Arbuscular mycorrhizal fungi (AMF) [102]. From experimental evidence, such a combination can mitigate drought-related stress on plants growth by improving the WHC [103].

Biochar has diversified mitigating impacts on salt-induced stress. Mechanistically, biochar surfaces could interact with soil constituents, including soil minerals, ions, and organic matter. Therefore, it is likely that biochar could buffer soil salt since it could provide exchange sites for ionic salts. Our understanding of how biochar surfaces could affect soil ionic salts is not complete since it is unclear how effective it would be in reducing salt stress when the ions are retained in the ion-exchange sites. In addition, biochar often carries some nutrients, including basic cations $\left(\mathrm{Ca}^{2+}, \mathrm{Mg}^{2+}\right.$ and $\left.\mathrm{K}^{+}\right)$that could reduce salt stress. The mineral concentration in biochar is high when it is produced from manures or grasses. However, biochar application at high rates could increase salt stress by adding salts and small organic molecules. One of the most important aspects of biochar is that it is porous and, thus, carries large SSA. This large SSA contributes to buffering of salts while improving water retention in soil (Figure 6). Given that the biochar's pores are narrow, it is not certain whether the water retained in the pore would help plant water uptake. 


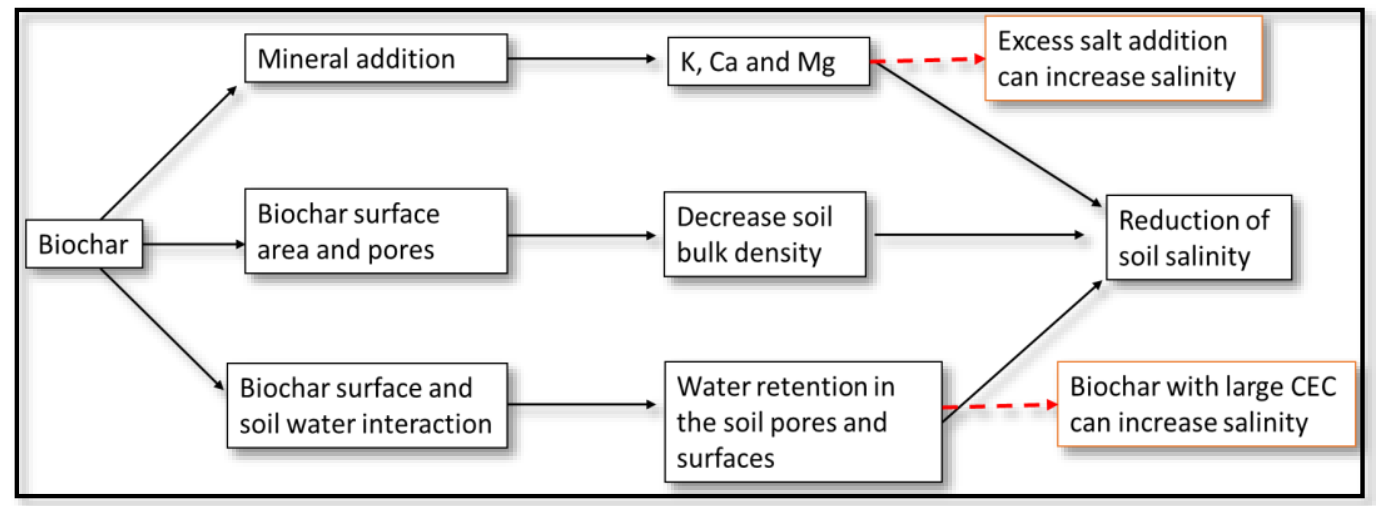

Figure 6. Role of biochar in the remediation of saline soils.

\subsection{Management of Polluted Soils}

The use of biochar for pollution remediation has seen a significant increase in recent times due to abundant literature attesting to the versatile nature of biochar [104,105]. As pointed out earlier, using biochar as a soil amendment material increases soil $\mathrm{pH}, \mathrm{CEC}$, and OM content. By improving these parameters, biochar indirectly boosts the ability of soils to retain pollutants such as heavy metals [106], dyes [107], antibiotics [108], etc. The charge states of both pollutants (organic and inorganic) at low soil $\mathrm{pH}$ make them highly available for plants and other life forms, thereby significantly increasing their toxicity potential [109]. Amending polluted soils with biochar improves pollutant retention by (i) enhancing electrostatic adsorption of cationic pollutants, (ii) introducing more $\mathrm{O}$ containing organic units for complexation with or degradation of pollutants, (iii) reducing pollutants to less toxic forms, (iv) precipitating pollutants as non-toxic salts, etc. The immobilization of heavy metals such as Lead $(\mathrm{Pb})$ in polluted soils was shown to follow the listed mechanisms and with the precipitation of less toxic $\mathrm{Pb}_{5}\left(\mathrm{PO}_{4}\right)_{3} \mathrm{Cl}, \mathrm{Pb}_{3}\left(\mathrm{CO}_{3}\right)_{2}(\mathrm{OH})_{2}$, and $\mathrm{Pb}(\mathrm{OH})_{2}[110,111]$. A direct consequence of increased immobilization of pollutants in soils is reduced bioavailability. For instance, the uptake of heavy metals $(\mathrm{Cr}, \mathrm{Ni}, \mathrm{Cu}, \mathrm{Pb}$, $\mathrm{Zn}$, and $\mathrm{Cd}$ ) by above- and below-ground parts of rice was significantly inhibited when a paddy soil was amended with biochar [104]. Similarly, biochar amendment improved growth parameters of maize plants cultivated under $\mathrm{Pb}$ toxicity [112], reduced the uptake of organic pollutants by plants $[113,114]$, enhanced adsorption and degradation of organic pollutants in soils [115], and improved microbial abundance in polluted soils [75].

\subsection{Mitigation of Greenhouse Gas Emission}

The use of pyrolysis for biochar production has been termed "a carbon-neutral process" since byproducts and emissions can be captured and none are emitted (https://biochar-us. org/biochar-slows-climate-change (accessed on 21 May 2021)). However, in most cases, half of the original carbon of the biomass can be emitted if it is not trapped. Despite this, pyrolysis and biochar are considered carbon-negative technology since this technology can reduce carbon footprint in several other ways. First, amending soils with biochar can mitigate climate change due to the recalcitrant nature of biochar carbon. The stable nature of biochar carbon implies that it can be retained in the soil for decades to centuries, if not millennia. In doing so, it can induce the stabilization of other carbon forms in the soil by accelerating organo-mineral complexation (as discussed in the previous section), thereby reducing $\mathrm{CO}_{2}$ emission [116]. Across studies, it has been shown that biochar changes greenhouse gas (GHG) emission from soils through multiple ways, including (a) changes in soil nutrient dynamics, (b) changes in soil $\mathrm{pH}, \mathrm{EC}$, and Eh, and (c) changes in crop productivity, although diverse effects have also been reported (see Text S3 for details). For instance, a one-year field experiment showed that the application of NPK fertilizer to agricultural soils can increase $\mathrm{N}_{2} \mathrm{O}$ emissions. Contrarily, the application of wood residue-derived biochar to the same soil significantly inhibited $\mathrm{N}_{2} \mathrm{O}$ emission and enhanced 
C storage [117]. The altering effect of biochar on GHG emission depends on biochar type and ageing conditions, soil type, the water-filled pore space [118], and its ability to change the structure of the soil microbial community [71,72]. Nevertheless, biochars have the potential to act as an excellent adsorbent for gaseous ozone and $\mathrm{NO}_{3}{ }^{-}$[119], $\mathrm{NH}_{4}{ }^{+}$[120], dissolved organic carbon, and other nutrients [121]. Thus, the estimation of these compounds via extraction from biochar-amended soils or evaluation of the released gases may underestimate their content.

\subsection{Guidelines for Biochar Application}

As discussed in the previous sections, biochar's interactions with soils can be quite diverse based on their properties (Figure S4). For instance, biochar with larger SSA but with neutral to positive surfaces has been shown to have minimal impacts on crop productivity when applied to clay soil. However, the carbon sequestration potential is high when biochar with a low $\mathrm{C} / \mathrm{H}$ ratio is applied to clay soils. However, if biochar with large negative surfaces is applied on the same soil, the impacts may be slightly positive on crop productivity. When biochar with a large negative charge is applied to sand or loamy soil, these effects can be positive. Similar positive effects were also reported for acidic soils from the application of biochar with diverse properties [27]. With these guiding results, biochar properties can be designed for achieving specific benefits.

\subsection{Ecotoxicology and Negative Effects of Biochar}

Although biochar has the potential to mitigate climate change due to its high carbon resilience and its usefulness in amending soils to improve fertility and remediate polluted soils, hazardous compounds-with damaging effects on plants [122] and soil organisms [123-127] — may be found in biochar. Generally, the agricultural ecosystem is primarily influenced by biochar addition in three ways: contaminants in biochar, phytotoxicity, and biochar-induced changing soil environment. Contaminants such as polycyclic aromatic hydrocarbons (PAHs), polychlorinated dibenzo-p-dioxins, volatile organic compounds, and heavy metals may be present in biochar due to the presence of contaminants in the feedstock. Thus, feedstock selection for making biochar is vital to reduce the environmental risk.

The negative effect of biochar on plant growth has been reported in several studies. Some authors have reported a significant reduction in plant biomass after biochar application at a rate of $10 \mathrm{tha}^{-1}$ [128], while others observed the inhibition of seed germination [129] and a reduction in seedling growth metrics [130]. The ecotoxicological effect of biochars depends on the pyrolysis temperature and feedstock type, with biochar produced at $800{ }^{\circ} \mathrm{C}$ showing increased negative effects on plants and arthropods compared to those at 400 and $600{ }^{\circ} \mathrm{C}$ [131]. Many studies have attributed the negative effect of biochar on plant growth to environmentally persistent free radicals (EPFRs) formed during pyrolysis $[132,133]$ and to heavy metals within the biochar [130]. For instance, Liao et al. [132] observed that amending soils with biochar had an inhibitory effect on seed germination and plant growth. The authors attributed this observation to the ability of biochar to induce oxidative stress in plants. Nevertheless, the production of EPFRs can be effectively reduced by increasing the pyrolysis temperature above $500{ }^{\circ} \mathrm{C}$ [134].

\section{Conclusions and Future Research Directions}

This review presents a systematic and critical analysis of the interaction(s) of biochar with soils and its effect on soil properties and functions. The interactions are often multifaceted and depend on both biochar and soil properties. Therefore, both biochar and soil properties should be considered for harvesting the benefits of biochars. Specifically, a matrix of biochar versus soil properties can be developed for guiding the decision-makers for large-scale biochar applications. Despite the increasing number of research with biochar in the recent decade, there are few field studies with biochar. Long-term field studies are required to verify results from short-term laboratory studies so that benefits of biochar 
application (e.g., climate change mitigation, immobilization of pollutants, inhibition of acidification, etc.) would be harvested at a larger scale. The specific recommendations are-

(a) The need for technological maturity: Long-term studies are required to understand the future of the currently applied biochar. Few studies have attempted to examine the future role of biochar using artificial conditions. However, real field conditions may differ and thus, the need for long-term field studies.

(b) Accreditation of biochar: Given thousands of studies reporting diverse results, it is difficult for practitioners to use biochar and, if so, determine which of the types to use. Therefore, an international body can be formed to accredit the quality of biochar. A generalized guideline can be prepared for preparing, testing, and applying biochars for achieving a target, while equal importance needs to be paid for the long-term effects of biochar because the role of currently applied biochar may be reversed in the future.

(c) Biochar-based composites: Development and application of biochar-based composite and fertilizers can be one of the new dimensions of biochar research since there is a higher chance of obtaining biochar-nutrient/contaminants interactions than their direct application to soils. However, detailed studies are required before advocating any large-scale application.

(d) Cost-effective biochar production: Research is needed to tailor technologies that can help to produce biochar at a low cost. One of the big challenges is that many large biochar production companies are struggling to sustain their business. Efforts are to be made to harvest all possible benefits, including recycling energy. Moreover, obtaining a sustainable source of biomass is needed. The use of waste biomass (municipal waste) can be an option for that. However, suitable technologies are required for handling diverse biomass.

Supplementary Materials: The following are available online at https://www.mdpi.com/article/10 .3390/su132413726/s1, Figure S1: Changes in soil aggregation after biochar amendments; Figure S2: The relationship between increase in soil water holding capacity (WHC) and biochar application rate for a loamy sand soil; Figure S3: Schematic of biochar's role on nutrient dynamics, management of soil acidification, changes in crop performance, and pollution remediation; Figure S4: Guiding principles of biochar application to soil; Table S1: The physicochemical properties of biochar produced from various biomass precursors using varying pyrolytic conditions; Table S2: Estimated chemical properties of biochar; Table S3: Effect of biochar incorporation on soil physicochemical properties; Table S4: Effect of biochar on soil exchangeable properties; Table S5: Impact of biochar on dynamics of soil phosphorus.

Author Contributions: Conceptualization, J.N.N., M.A.-A.B. and S.M.; methodology, J.N.N.; software, J.N.N., M.A.-A.B. and S.M.; validation, R.X. and R.S.; formal analysis, J.N.N. and M.A.-A.B.; data curation, J.N.N., M.A.-A.B., S.M., and M.A.K.; writing-original draft preparation, J.N.N., M.A.-A.B., S.M., R.S., M.A.K., K.M. and R.X.; writing-review and editing, J.N.N., M.A.-A.B., S.M., R.S., M.A.K., K.M. and R.X.; supervision, R.X.; project administration, J.N.N.; funding acquisition, R.S. and R.X. All authors have read and agreed to the published version of the manuscript.

Funding: This work was supported by the National Natural Science Foundation of China (Grant No. U19A2046); the Chinese Academy of Sciences President's International Fellowship Initiative (PIFI, No. 2021PC0066); the National Natural Science Foundation of China (Grant No. 41907019); the Natural Science Foundation of Jiangsu Province, China (Grant No. BK20191103).

Institutional Review Board Statement: Not applicable.

Informed Consent Statement: Not applicable.

Data Availability Statement: Not applicable.

Acknowledgments: We acknowledge all authors whose work paved the way for this review.

Conflicts of Interest: The authors declare that they have no known competing financial interests or personal relationships that could have appeared to influence the work reported in this paper. 


\section{References}

1. Rabot, E.; Wiesmeier, M.; Schlüter, S.; Vogel, H.J. Soil structure as an indicator of soil functions: A review. Geoderma 2018, 314, 122-137. [CrossRef]

2. Ponge, J.-F. The soil as an ecosystem. Biol. Fertil. Soils 2015, 51, 645-648. [CrossRef]

3. Xu, R.K.; Coventry, D.R.R. Soil pH changes associated with lupin and wheat plant materials incorporated in a red-brown earth soil. Plant Soil 2003, 250, 113-119. [CrossRef]

4. Yuan, J.H.; Xu, R.K.; Qian, W.; Wang, R.H. Comparison of the ameliorating effects on an acidic ultisol between four crop straws and their biochars. J. Soils Sediments 2011, 11, 741-750. [CrossRef]

5. Shi, R.Y.; Hong, Z.N.; Li, J.Y.; Jiang, J.; al Baquy, M.A.; Xu, R.K.; Qian, W. Mechanisms for Increasing the pH Buffering Capacity of an Acidic Ultisol by Crop Residue-Derived Biochars. J. Agric. Food Chem. 2017, 65, 8111-8119. [CrossRef]

6. Shi, R.Y.; Li, J.Y.; Jiang, J.; Kamran, M.A.; Xu, R.K.; Qian, W. Incorporation of corn straw biochar inhibited the re-acidification of four acidic soils derived from different parent materials. Environ. Sci. Pollut. Res. 2018, 25, 9662-9672. [CrossRef] [PubMed]

7. da Costa, C.H.M.; Crusciol, C.A.C. Long-term effects of lime and phosphogypsum application on tropical no-till soybean-oatsorghum rotation and soil chemical properties. Eur. J. Agron. 2016, 74, 119-132. [CrossRef]

8. Natasha, N.; Shahid, M.; Khalid, S.; Bibi, I.; Naeem, M.A.; Niazi, N.K.; Tack, F.M.G.; Ippolito, J.A.; Rinklebe, J. Influence of biochar on trace element uptake, toxicity and detoxification in plants and associated health risks: A critical review. Crit. Rev. Environ. Sci. Technol. 2021. [CrossRef]

9. Oni, B.A.; Oziegbe, O.; Olawole, O.O. Significance of biochar application to the environment and economy. Ann. Agric. Sci. 2019, 64, 222-236. [CrossRef]

10. Mandal, S.; Pu, S.; Adhikari, S.; Ma, H.; Kim, D.H.; Bai, Y.; Hou, D. Progress and future prospects in biochar composites: Application and reflection in the soil environment. Crit. Rev. Environ. Sci. Technol. 2021, 51, 219-271. [CrossRef]

11. Premarathna, K.S.D.S.D.; Rajapaksha, A.U.; Sarkar, B.; Kwon, E.E.; Bhatnagar, A.; Ok, Y.S.; Vithanage, M. Biochar-based engineered composites for sorptive decontamination of water: A review. Chem. Eng. J. 2019, 372, 536-550. [CrossRef]

12. Oliveira, F.R.; Patel, A.K.; Jaisi, D.P.; Adhikari, S.; Lu, H.; Khanal, S.K. Environmental application of biochar: Current status and perspectives. Bioresour. Technol. 2017, 246, 110-122. [CrossRef]

13. Zhang, Y.; Wang, J.; Feng, Y. The effects of biochar addition on soil physicochemical properties: A review. Catena $2021,202$. [CrossRef]

14. Dai, Z.; Zhang, X.; Tang, C.; Muhammad, N.; Wu, J.; Brookes, P.C.; Xu, J. Potential role of biochars in decreasing soil acidificationA critical review. Sci. Total Environ. 2017, 581-582, 601-611. [CrossRef]

15. Shi, R.Y.; Li, J.Y.; Ni, N.; Xu, R.K. Understanding the biochar's role in ameliorating soil acidity. J. Integr. Agric. 2019, 18, 1508-1517. [CrossRef]

16. Ronsse, F.; van Hecke, S.; Dickinson, D.; Prins, W. Production and characterization of slow pyrolysis biochar: Influence of feedstock type and pyrolysis conditions. GCB Bioenergy 2013, 5, 104-115. [CrossRef]

17. Figueiredo, C.; Lopes, H.; Coser, T.; Vale, A.; Busato, J.; Aguiar, N.; Novotny, E.; Canellas, L. Influence of pyrolysis temperature on chemical and physical properties of biochar from sewage sludge. Arch. Agron. Soil Sci. 2018, 64, 881-889. [CrossRef]

18. Fidel, R.B.; Laird, D.A.; Thompson, M.L.; Lawrinenko, M. Characterization and quantification of biochar alkalinity. Chemosphere 2017, 167, 367-373. [CrossRef]

19. Ahmad, M.; Lee, S.S.; Dou, X.; Mohan, D.; Sung, J.-K.K.; Yang, J.E.; Ok, Y.S. Effects of pyrolysis temperature on soybean stoverand peanut shell-derived biochar properties and TCE adsorption in water. Bioresour. Technol. 2012, 118, 536-544. [CrossRef] [PubMed]

20. Ippolito, J.A.; Cui, L.; Kammann, C.; Wrage-Mönnig, N.; Estavillo, J.M.; Fuertes-Mendizabal, T.; Cayuela, M.L.; Sigua, G.; Novak, J.; Spokas, K.; et al. Feedstock choice, pyrolysis temperature and type influence biochar characteristics: A comprehensive meta-data analysis review. Biochar 2020, 2, 421-438. [CrossRef]

21. Wang, S.; Zhang, H.; Huang, H.; Xiao, R.; Li, R.; Zhang, Z. Influence of temperature and residence time on characteristics of biochars derived from agricultural residues: A comprehensive evaluation. Process Saf. Environ. Prot. 2020, 139, $218-229$. [CrossRef]

22. Pan, J.; Ma, J.; Liu, X.; Zhai, L.; Ouyang, X.; Liu, H. Effects of different types of biochar on the anaerobic digestion of chicken manure. Bioresour. Technol. 2019, 275, 258-265. [CrossRef]

23. Yuan, J.H.; Xu, R.K.; Zhang, H. The forms of alkalis in the biochar produced from crop residues at different temperatures. Bioresour. Technol. 2011, 102, 3488-3497. [CrossRef] [PubMed]

24. Yuan, J.H.; Xu, R.K. Effects of biochars generated from crop residues on chemical properties of acid soils from tropical and subtropical China. Soil Res. 2012, 50, 570-578. [CrossRef]

25. Xu, R.K.; Zhao, A.Z.; Yuan, J.H.; Jiang, J. pH buffering capacity of acid soils from tropical and subtropical regions of China as influenced by incorporation of crop straw biochars. J. Soils Sediments 2012, 12, 494-502. [CrossRef]

26. He, X.; Hong, Z.N.; Jiang, J.; Dong, G.; Liu, H.; Xu, R.K. Enhancement of Cd(II) adsorption by rice straw biochar through oxidant and acid modifications. Environ. Sci. Pollut. Res. 2021, 28, 42787-42797. [CrossRef]

27. Mia, S.; Dijkstra, F.A.; Singh, B. Long-Term Aging of Biochar: A Molecular Understanding with Agricultural and Environmental Implications. Adv. Agron. 2017, 141, 1-51. [CrossRef] 
28. Wang, J.; Wang, S. Preparation, modification and environmental application of biochar: A review. J. Clean. Prod. 2019, 227, 1002-1022. [CrossRef]

29. Tao, Q.; Li, B.; Li, Q.; Han, X.; Jiang, Y.; Jupa, R.; Wang, C.; Li, T. Simultaneous remediation of sediments contaminated with sulfamethoxazole and cadmium using magnesium-modified biochar derived from Thalia dealbata. Sci. Total Environ. 2019, 659, 1448-1456. [CrossRef]

30. He, X.; Jiang, J.; Hong, Z.; Pan, X.; Dong, Y.; Xu, R. Effect of aluminum modification of rice straw-based biochar on arsenate adsorption. J. Soils Sediments 2020, 20, 3073-3082. [CrossRef]

31. Peng, G.; Jiang, S.; Wang, Y.; Zhang, Q.; Cao, Y.; Sun, Y.; Zhang, W.; Wang, L. Synthesis of Mn/Al double oxygen biochar from dewatered sludge for enhancing phosphate removal. J. Clean. Prod. 2020, 251. [CrossRef]

32. Ma, Y.; Liu, W.J.; Zhang, N.; Li, Y.S.; Jiang, H.; Sheng, G.P. Polyethylenimine modified biochar adsorbent for hexavalent chromium removal from the aqueous solution. Bioresour. Technol. 2014, 169, 403-408. [CrossRef] [PubMed]

33. Ali, S.; Rizwan, M.; Qayyum, M.F.; Ok, Y.S.; Ibrahim, M.; Riaz, M.; Arif, M.S.; Hafeez, F.; Al-Wabel, M.I.; Shahzad, A.N. Biochar soil amendment on alleviation of drought and salt stress in plants: A critical review. Environ. Sci. Pollut. Res. 2017, 24, 12700-12712. [CrossRef]

34. Kammann, C.I.; Linsel, S.; Gößling, J.W.; Koyro, H.W. Influence of biochar on drought tolerance of Chenopodium quinoa Willd and on soil-plant relations. Plant Soil 2011, 345, 195-210. [CrossRef]

35. Zhou, H.; Fang, H.; Zhang, Q.; Wang, Q.; Chen, C.; Mooney, S.J.; Peng, X.; Du, Z. Biochar enhances soil hydraulic function but not soil aggregation in a sandy loam. Eur. J. Soil Sci. 2019, 70, 291-300. [CrossRef]

36. Burrell, L.D.; Zehetner, F.; Rampazzo, N.; Wimmer, B.; Soja, G. Long-term effects of biochar on soil physical properties. Geoderma 2016, 282, 96-102. [CrossRef]

37. Omondi, M.O.; Xia, X.; Nahayo, A.; Liu, X.; Korai, P.K.; Pan, G. Quantification of biochar effects on soil hydrological properties using meta-analysis of literature data. Geoderma 2016, 274, 28-34. [CrossRef]

38. Yargicoglu, E.N.; Sadasivam, B.Y.; Reddy, K.R.; Spokas, K. Physical and chemical characterization of waste wood derived biochars. Waste Manag. 2015, 36, 256-268. [CrossRef]

39. Barnes, R.T.; Gallagher, M.E.; Masiello, C.A.; Liu, Z.; Dugan, B. Biochar-induced changes in soil hydraulic conductivity and dissolved nutrient fluxes constrained by laboratory experiments. PLoS ONE 2014, 9, e108340. [CrossRef]

40. Lim, T.J.; Spokas, K.A.; Feyereisen, G.; Novak, J.M. Predicting the impact of biochar additions on soil hydraulic properties. Chemosphere 2016, 142, 136-144. [CrossRef]

41. Yu, O.-Y.Y.; Harper, M.; Hoepfl, M.; Domermuth, D. Characterization of biochar and its effects on the water holding capacity of loamy sand soil: Comparison of hemlock biochar and switchblade grass biochar characteristics. Environ. Prog. Sustain. Energy 2017, 36, 1474-1479. [CrossRef]

42. Verheijen, F.G.A.; Zhuravel, A.; Silva, F.C.; Amaro, A.; Ben-Hur, M.; Keizer, J.J. The influence of biochar particle size and concentration on bulk density and maximum water holding capacity of sandy vs sandy loam soil in a column experiment. Geoderma 2019, 347, 194-202. [CrossRef]

43. Yuan, J.H.; Xu, R.K. The amelioration effects of low temperature biochar generated from nine crop residues on an acidic Ultisol. Soil Use Manag. 2011, 27, 110-115. [CrossRef]

44. Mukhopadhyay, S.; Masto, R.E.; Tripathi, R.C.; Srivastava, N.K. Application of Soil Quality Indicators for the Phytorestoration of Mine Spoil Dumps, In Phytomanagement of Polluted Sites; Elsevier: Amsterdam, The Netherlands, 2018; pp. 361-388. [CrossRef]

45. Jiang, J.; Xu, R.K.; Jiang, T.Y.; Li, Z. Immobilization of $\mathrm{Cu}(\mathrm{II}), \mathrm{Pb}(\mathrm{II})$ and $\mathrm{Cd}(\mathrm{II})$ by the addition of rice straw derived biochar to a simulated polluted Ultisol. J. Hazard. Mater. 2012, 229-230, 145-150. [CrossRef] [PubMed]

46. Tong, X.J.; Li, J.Y.; Yuan, J.H.; Xu, R.K. Adsorption of $\mathrm{Cu}(\mathrm{II})$ by biochars generated from three crop straws. Chem. Eng. J. 2011, 172, 828-834. [CrossRef]

47. Shi, R.Y.; Hong, Z.N.; Li, J.Y.; Jiang, J.; Kamran, M.A.; Xu, R.K.; Qian, W. Peanut straw biochar increases the resistance of two Ultisols derived from different parent materials to acidification: A mechanism study. J. Environ. Manag. 2018, 210, 171-179. [CrossRef]

48. Qian, L.; Chen, B.; Hu, D. Effective alleviation of aluminum phytotoxicity by manure-derived biochar. Environ. Sci. Technol. 2013, 47, 2737-2745. [CrossRef]

49. Xu, R.K.; Xiao, S.C.; Yuan, J.H.; Zhao, A.Z. Adsorption of methyl violet from aqueous solutions by the biochars derived from crop residues. Bioresour. Technol. 2011, 102, 10293-10298. [CrossRef]

50. Xu, R.; Li, C.; Ji, G. Effect of low-molecular-weight organic anions on electrokinetic properties of variable charge soils. J. Colloid Interface Sci. 2004, 277, 243-247. [CrossRef]

51. Sun, Q.; Meng, J.; Lan, Y.; Shi, G.; Yang, X.; Cao, D.; Chen, W.; Han, X. Long-term effects of biochar amendment on soil aggregate stability and biological binding agents in brown earth. Catena 2021, 205. [CrossRef]

52. Han, L.; Sun, K.; Yang, Y.; Xia, X.; Li, F.; Yang, Z.; Xing, B. Biochar's stability and effect on the content, composition and turnover of soil organic carbon. Geoderma 2020, 364. [CrossRef]

53. Amoakwah, E.; Frimpong, K.A.; Arthur, E. Corn Cob Biochar Improves Aggregate Characteristics of a Tropical Sandy Loam. Soil Sci. Soc. Am. J. 2017, 81, 1054-1063. [CrossRef]

54. Fu, Q.; Zhao, H.; Li, H.; Li, T.; Hou, R.; Liu, D.; Ji, Y.; Gao, Y.; Yu, P. Effects of biochar application during different periods on soil structures and water retention in seasonally frozen soil areas. Sci. Total Environ. 2019, 694. [CrossRef] 
55. Islam, M.U.; Jiang, F.; Guo, Z.; Peng, X. Does biochar application improve soil aggregation? A meta-analysis. Soil Tillage Res. 2021, 209. [CrossRef]

56. Herath, H.M.S.K.; Camps-Arbestain, M.; Hedley, M. Effect of biochar on soil physical properties in two contrasting soils: An Alfisol and an Andisol. Geoderma 2013, 209-210, 188-197. [CrossRef]

57. Blanco-Canqui, H. Biochar and Soil Physical Properties. Soil Sci. Soc. Am. J. 2017, 81, 687-711. [CrossRef]

58. Kleber, M.; Eusterhues, K.; Keiluweit, M.; Mikutta, C.; Mikutta, R.; Nico, P.S. Mineral-Organic Associations: Formation, Properties, and Relevance in Soil Environments. Adv. Agron. 2015, 130, 1-140. [CrossRef]

59. Song, Y.F.; Zhang, Q.Q.; Wu, Z.; Duan, P.P.; Xiong, Z.Q. Field-aged biochar improves soil aggregation stability and phosphorus use efficiency in paddy field. J. Plant Nutr. Fertil. 2020, 26, 613-621. [CrossRef]

60. Burgeon, V.; Fouché, J.; Leifeld, J.; Chenu, C.; Cornélis, J.T. Organo-mineral associations largely contribute to the stabilization of century-old pyrogenic organic matter in cropland soils. Geoderma 2021, 388. [CrossRef]

61. Xu, X.; Zhao, Y.; Sima, J.; Zhao, L.; Mašek, O.; Cao, X. Indispensable role of biochar-inherent mineral constituents in its environmental applications: A review. Bioresour. Technol. 2017, 241, 887-899. [CrossRef]

62. Six, J.; Elliott, E.T.; Paustian, K. Soil macroaggregate turnover and microaggregate formation: A mechanism for C sequestration under no-tillage agriculture. Soil Biol. Biochem. 2000, 32, 2099-2103. [CrossRef]

63. Six, J.; Bossuyt, H.; Degryze, S.; Denef, K. A history of research on the link between (micro)aggregates, soil biota, and soil organic matter dynamics. Soil Tillage Res. 2004. [CrossRef]

64. Cen, R.; Feng, W.; Yang, F.; Wu, W.; Liao, H.; Qu, Z. Effect mechanism of biochar application on soil structure and organic matter in semi-arid areas. J. Environ. Manag. 2021, 286. [CrossRef] [PubMed]

65. Abbas, M.; Ijaz, S.S.; Ansar, M.; Hussain, Q.; Hassan, A.; Akmal, M.; Tahir, M.; Iqbal, M.; Bashir, K. Sana-ur-Rehman, Impact of biochar with different organic materials on carbon fractions, aggregate size distribution, and associated polysaccharides and soil moisture retention in an arid soil. Arab. J. Geosci. 2019, 12, 626. [CrossRef]

66. Yu, Z.; Zheng, Y.; Zhang, J.; Zhang, C.; Ma, D.; Chen, L.; Cai, T. Importance of soil interparticle forces and organic matter for aggregate stability in a temperate soil and a subtropical soil. Geoderma 2020, 362. [CrossRef]

67. Zhao, Z.; Zhou, W. Insight into interaction between biochar and soil minerals in changing biochar properties and adsorption capacities for sulfamethoxazole. Environ. Pollut. 2019, 245, 208-217. [CrossRef]

68. Sun, F.; Lu, S. Biochars improve aggregate stability, water retention, and pore-space properties of clayey soil. J. Plant Nutr. Soil Sci. 2014, 177, 26-33. [CrossRef]

69. Pituello, C.; Ferro, N.D.; Francioso, O.; Simonetti, G.; Berti, A.; Piccoli, I.; Pisi, A.; Morari, F. Effects of biochar on the dynamics of aggregate stability in clay and sandy loam soils. Eur. J. Soil Sci. 2018, 69, 827-842. [CrossRef]

70. Zhang, Q.; Du, Z.L.; Lou, Y.; He, X. A one-year short-term biochar application improved carbon accumulation in large macroaggregate fractions. Catena 2015, 127, 26-31. [CrossRef]

71. Anderson, C.R.; Condron, L.M.; Clough, T.J.; Fiers, M.; Stewart, A.; Hill, R.A.; Sherlock, R.R. Biochar induced soil microbial community change: Implications for biogeochemical cycling of carbon, nitrogen and phosphorus. Pedobiologia 2011, 54, 309-320. [CrossRef]

72. Yu, J.; Deem, L.M.; Crow, S.E.; Deenik, J.L.; Penton, C.R. Biochar application influences microbial assemblage complexity and composition due to soil and bioenergy crop type interactions. Soil Biol. Biochem. 2018, 117, 97-107. [CrossRef]

73. Bi, Q.F.; Chen, Q.H.; Yang, X.R.; Li, H.; Zheng, B.X.; Zhou, W.W.; Liu, X.X.; Dai, P.B.; Li, K.J.; Lin, X.Y. Effects of combined application of nitrogen fertilizer and biochar on the nitrification and ammonia oxidizers in an intensive vegetable soil. $A M B$ Express. 2017, 7, 198. [CrossRef]

74. Shi, R.Y.; Ni, N.; Nkoh, J.N.; Li, J.Y.; Xu, R.K.; Qian, W. Beneficial dual role of biochars in inhibiting soil acidification resulting from nitrification. Chemosphere 2019, 234, 43-51. [CrossRef] [PubMed]

75. Song, Y.; Bian, Y.; Wang, F.; Xu, M.; Ni, N.; Yang, X.; Gu, C.; Jiang, X. Dynamic Effects of Biochar on the Bacterial Community Structure in Soil Contaminated with Polycyclic Aromatic Hydrocarbons. J. Agric. Food Chem. 2017, 65, 6789-6796. [CrossRef]

76. Kim, J.S.; Sparovek, G.; Longo, R.M.; de Melo, W.J.; Crowley, D. Bacterial diversity of terra preta and pristine forest soil from the Western Amazon. Soil Biol. Biochem. 2007, 39, 684-690. [CrossRef]

77. Xu, H.J.; Wang, X.H.; Li, H.; Yao, H.Y.; Su, J.Q.; Zhu, Y.G. Biochar impacts soil microbial community composition and nitrogen cycling in an acidic soil planted with rape. Environ. Sci. Technol. 2014, 48, 9391-9399. [CrossRef] [PubMed]

78. Chen, J.; Liu, X.; Li, L.; Zheng, J.J.; Qu, J.; Zheng, J.J.; Zhang, X.; Pan, G. Consistent increase in abundance and diversity but variable change in community composition of bacteria in topsoil of rice paddy under short term biochar treatment across three sites from South China. Appl. Soil Ecol. 2015, 91, 68-79. [CrossRef]

79. Lu, H.; Yan, M.; Wong, M.H.; Mo, W.Y.; Wang, Y.; Chen, X.W.; Wang, J.J. Effects of biochar on soil microbial community and functional genes of a landfill cover three years after ecological restoration. Sci. Total Environ. 2020, 717. [CrossRef]

80. Ducey, T.; Novak, J.; Johnson, M. Effects of Biochar Blends on Microbial Community Composition in Two Coastal Plain Soils. Agriculture 2015, 5, 1060-1075. [CrossRef]

81. Luo, Y.; Durenkamp, M.; de Nobili, M.; Lin, Q.; Devonshire, B.J.; Brookes, P.C. Microbial biomass growth, following incorporation of biochars produced at $350^{\circ} \mathrm{C}$ or $700{ }^{\circ} \mathrm{C}$, in a silty-clay loam soil of high and low pH. Soil Biol. Biochem. 2013, 57, 513-523. [CrossRef] 
82. Pansu, M.; Gautheyrou, J. Handbook of Soil Analysis: Mineralogical, Organic and Inorganic Methods; Springer Science \& Business Media: Berlin/Heidelberg, Germany, 2006. [CrossRef]

83. Wang, F.; Wang, X.; Song, N. Biochar and vermicompost improve the soil properties and the yield and quality of cucumber (Cucumis sativus L.) grown in plastic shed soil continuously cropped for different years. Agric. Ecosyst. Environ. $2021,315$. [CrossRef]

84. Antonangelo, J.A.; Sun, X.; Zhang, H. The roles of co-composted biochar (COMBI) in improving soil quality, crop productivity, and toxic metal amelioration. J. Environ. Manag. 2021, 277. [CrossRef] [PubMed]

85. Shi, R.Y.; Ni, N.; Nkoh, J.N.; Dong, Y.; Zhao, W.R.; Pan, X.Y.; Li, J.Y.; Xu, R.K.; Qian, W. Biochar retards Al toxicity to maize (Zea mays L.) during soil acidification: The effects and mechanisms. Sci. Total Environ. 2020, 719, 137448. [CrossRef] [PubMed]

86. Zhao, W.R.; Li, J.Y.; Deng, K.Y.; Shi, R.Y.; Jiang, J.; Hong, Z.N.; Qian, W.; He, X.; Xu, R.K. Effects of crop straw biochars on aluminum species in soil solution as related with the growth and yield of canola (Brassica napus L.) in an acidic Ultisol under field condition. Environ. Sci. Pollut. Res. 2020, 27, 30178-30189. [CrossRef]

87. Yamamoto, Y. Aluminum toxicity in plant cells: Mechanisms of cell death and inhibition of cell elongation. Soil Sci. Plant Nutr. 2019, 65, 41-55. [CrossRef]

88. Jeffery, S.; Abalos, D.; Prodana, M.; Bastos, A.C.; van Groenigen, J.W.; Hungate, B.A.; Verheijen, F. Biochar boosts tropical but not temperate crop yields. Environ. Res. Lett. 2017, 12. [CrossRef]

89. Sultan, H.; Ahmed, N.; Mubashir, M.; Danish, S. Chemical production of acidified activated carbon and its influences on soil fertility comparative to thermo-pyrolyzed biochar. Sci. Rep. 2020, 10, 595. [CrossRef]

90. Mete, F.Z.; Mia, S.; Dijkstra, F.A.; Abuyusuf, M.; Hossain, A.S.M.I. Synergistic Effects of Biochar and NPK Fertilizer on Soybean Yield in an Alkaline Soil. Pedosphere 2015, 25, 713-719. [CrossRef]

91. Abrishamkesh, S.; Gorji, M.; Asadi, H.; Bagheri-Marandi, G.H.; Pourbabaee, A.A. Effects of rice husk biochar application on the propertiesof alkaline soil and lentil growth. Plant Soil Environ. 2015, 62, 475-482. [CrossRef]

92. Baigorri, R.; Francisco, S.S.; Urrutia, Ó.; García-Mina, J.M. Biochar-Ca and Biochar-Al/-Fe-Mediated Phosphate Exchange Capacity are Main Drivers of the Different Biochar Effects on Plants in Acidic and Alkaline Soils. Agronomy 2020, 10, 968. [CrossRef]

93. Chen, M.; Alim, N.; Zhang, Y.; Xu, N.; Cao, X. Contrasting effects of biochar nanoparticles on the retention and transport of phosphorus in acidic and alkaline soils. Environ. Pollut. 2018, 239, 562-570. [CrossRef]

94. Esfandbod, M.; Phillips, I.R.; Miller, B.; Rashti, M.R.; Lan, Z.M.; Srivastava, P.; Singh, B.; Chen, C.R. Aged acidic biochar increases nitrogen retention and decreases ammonia volatilization in alkaline bauxite residue sand. Ecol. Eng. 2017, 98, 157-165. [CrossRef]

95. Elkhlifi, Z.; Kamran, M.; Maqbool, A.; El-Naggar, A.; Ifthikar, J.; Parveen, A.; Bashir, S.; Rizwan, M.; Mustafa, A.; Irshad, S.; et al. Phosphate-lanthanum coated sewage sludge biochar improved the soil properties and growth of ryegrass in an alkaline soil. Ecotoxicol. Environ. Saf. 2021, 216, 112173. [CrossRef]

96. Wu, L.; Zhang, S.; Wang, J.; Ding, X. Phosphorus retention using iron (II/III) modified biochar in saline-alkaline soils: Adsorption, column and field tests. Environ. Pollut. 2020, 261, 114223. [CrossRef] [PubMed]

97. Qayyum, M.F.; Liaquat, F.; Rehman, R.A.; Gul, M.; Hye, M.Z.U.; Rizwan, M.; Rehaman, M.Z.U. Effects of co-composting of farm manure and biochar on plant growth and carbon mineralization in an alkaline soil. Environ. Sci. Pollut. Res. 2017, 24, 26060-26068. [CrossRef] [PubMed]

98. Parida, A.K.; Das, A.B. Salt tolerance and salinity effects on plants: A review. Ecotoxicol. Environ. Saf. 2005, 60, 324-349. [CrossRef]

99. Mona, S.; Bhateria, R.; Deepak, B.; Kiran, B.; Nisha, R. Biochar for Reclamation of Saline Soils. In Microorganisms in Saline Environments: Strategies and Functions; Springer: Cham, Switzerland, 2019; pp. 451-466. [CrossRef]

100. Song, Y.; Zhang, X.; Ma, B.; Chang, S.X.; Gong, J. Biochar addition affected the dynamics of ammonia oxidizers and nitrification in microcosms of a coastal alkaline soil. Biol. Fertil. Soils 2013, 50, 321-332. [CrossRef]

101. Cui, Q.; Xia, J.; Yang, H.; Liu, J.; Shao, P. Biochar and effective microorganisms promote Sesbania cannabina growth and soil quality in the coastal saline-alkali soil of the Yellow River Delta, China. Sci. Total Environ. 2021, 756, 143801. [CrossRef] [PubMed]

102. Yusif, S.A.; Dare, M.O. Effect of Biochar Application and Arbuscular Mycorrhizal Inoculation on Root Colonization and Soil Chemical Properties. Int. Ann. Sci. 2016, 1, 33-38. [CrossRef]

103. Hashem, A.; Kumar, A.; Al-Dbass, A.M.; Alqarawi, A.A.; Al-Arjani, A.B.F.; Singh, G.; Farooq, M.; Abd_Allah, E.F. Arbuscular mycorrhizal fungi and biochar improves drought tolerance in chickpea. Saudi J. Biol. Sci. 2019, 26, 614-624. [CrossRef]

104. Zhu, Q.; Wu, J.; Wang, L.; Yang, G.; Zhang, X. Effect of Biochar on Heavy Metal Speciation of Paddy Soil. Water Air Soil Pollut. 2015, 226. [CrossRef]

105. O'Connor, D.; Peng, T.; Zhang, J.; Tsang, D.C.W.; Alessi, D.S.; Shen, Z.; Bolan, N.S.; Hou, D. Biochar application for the remediation of heavy metal polluted land: A review of in situ field trials. Sci. Total Environ. 2018, 619-620, 815-826. [CrossRef]

106. Lu, K.; Yang, X.; Shen, J.; Robinson, B.; Huang, H.; Liu, D.; Bolan, N.; Pei, J.; Wang, H. Effect of bamboo and rice straw biochars on the bioavailability of $\mathrm{Cd}, \mathrm{Cu}, \mathrm{Pb}$ and $\mathrm{Zn}$ to Sedum plumbizincicola. Agric. Ecosyst. Environ. 2014, 191, 124-132. [CrossRef]

107. Chen, S.; Qin, C.; Wang, T.; Chen, F.; Li, X.; Hou, H.; Zhou, M. Study on the adsorption of dyestuffs with different properties by sludge-rice husk biochar: Adsorption capacity, isotherm, kinetic, thermodynamics and mechanism. J. Mol. Liq. 2019, 285, 62-74. [CrossRef]

108. Xu, Q.; Zhou, Q.; Pan, M.; Dai, L. Interaction between chlortetracycline and calcium-rich biochar: Enhanced removal by adsorption coupled with flocculation. Chem. Eng. J. 2020, 382. [CrossRef] 
109. O'Connor, D.; Hou, D.; Ok, Y.S.; Song, Y.; Sarmah, A.K.; Li, X.; Tack, F.M.G. Sustainable in situ remediation of recalcitrant organic pollutants in groundwater with controlled release materials: A review. J. Control. Release 2018, 283, 200-213. [CrossRef] [PubMed]

110. Ahmad, M.; Ok, Y.S.; Kim, B.-Y.Y.; Ahn, J.-H.H.; Lee, Y.H.; Zhang, M.; Moon, D.H.; Al-Wabel, M.I.; Lee, S.S. Impact of soybean stover- and pine needle-derived biochars on $\mathrm{Pb}$ and As mobility, microbial community, and carbon stability in a contaminated agricultural soil. J. Environ. Manag. 2016, 166, 131-139. [CrossRef]

111. Shen, Z.; Hou, D.; Jin, F.; Shi, J.; Fan, X.; Tsang, D.C.W.; Alessi, D.S. Effect of production temperature on lead removal mechanisms by rice straw biochars. Sci. Total Environ. 2019, 655, 751-758. [CrossRef]

112. Ahmad, M.; Lee, S.S.S.-E.E.S.S.; Lim, J.E.; Lee, S.S.S.-E.E.S.S.; Cho, J.S.; Moon, D.H.; Hashimoto, Y.; Ok, Y.S. Speciation and phytoavailability of lead and antimony in a small arms range soil amended with mussel shell, cow bone and biochar: EXAFS spectroscopy and chemical extractions. Chemosphere 2014, 95, 433-441. [CrossRef] [PubMed]

113. Ni, N.; Shi, R.; Liu, Z.; Bian, Y.; Wang, F.; Song, Y.; Jiang, X. Effects of biochars on the bioaccessibility of phenanthrene/pyrene/zinc/lead and microbial community structure in a soil under aerobic and anaerobic conditions. J. Environ. Sci. 2018, 63, 296-306. [CrossRef]

114. Ni, N.; Song, Y.; Shi, R.; Liu, Z.; Bian, Y.; Wang, F.; Yang, X.; Gu, C.; Jiang, X. Biochar reduces the bioaccumulation of PAHs from soil to carrot (Daucus carota L.) in the rhizosphere: A mechanism study. Sci. Total Environ. 2017, 601-602, 1015-1023. [CrossRef] [PubMed]

115. Wu, C.; Liu, X.; Wu, X.; Dong, F.; Xu, J.; Zheng, Y. Sorption, degradation and bioavailability of oxyfluorfen in biochar-amended soils. Sci. Total Environ. 2019, 658, 87-94. [CrossRef]

116. Spokas, K.; Reicosky, D. Impacts of sixteen different biochars on soil greenhouse gas production. Ann. Environ. Sci. 2009, 3, 4. Available online: https:/ / www.researchgate.net/publication/48856254 (accessed on 10 November 2021).

117. Ginebra, M.; Muñoz, C.; Calvelo-Pereira, R.; Doussoulin, M.; Zagal, E. Biochar impacts on soil chemical properties, greenhouse gas emissions and forage productivity: A field experiment. Sci. Total Environ. 2022, 806. [CrossRef] [PubMed]

118. Singh, B.P.; Hatton, B.J.; Singh, B.; Cowie, A.L.; Kathuria, A. Influence of Biochars on Nitrous Oxide Emission and Nitrogen Leaching from Two Contrasting Soils. J. Environ. Qual. 2010, 39, 1224-1235. [CrossRef]

119. Zhou, L.; Richard, C.; Ferronato, C.; Chovelon, J.M.; Sleiman, M. Investigating the performance of biomass-derived biochars for the removal of gaseous ozone, adsorbed nitrate and aqueous bisphenol A. Chem. Eng. J. 2018, 334, 2098-2104. [CrossRef]

120. Chen, L.; Chen, X.L.; Zhou, C.H.; Yang, H.M.; Ji, S.F.; Tong, D.S.; Zhong, Z.K.; Yu, W.H.; Chu, M.Q. Environmental-friendly montmorillonite-biochar composites: Facile production and tunable adsorption-release of ammonium and phosphate. J. Clean. Prod. 2017, 156, 648-659. [CrossRef]

121. Lehmann, J.; Joseph, S. Biochar for Environmental Management-Science, Technology and Implementation, 2nd ed.; Routledge: Abingdon, UK, 2015.

122. Gascó, G.; Cely, P.; Paz-Ferreiro, J.; Plaza, C.; Méndez, A. Relation between biochar properties and effects on seed germination and plant development. Biol. Agric. Hortic. 2016, 32, 237-247. [CrossRef]

123. Godlewska, P.; Ok, Y.S.; Oleszczuk, P. THE DARK SIDE OF BLACK GOLD: Ecotoxicological aspects of biochar and biocharamended soils. J. Hazard. Mater. 2021, 403, 123833. [CrossRef] [PubMed]

124. Kavitha, B.; Reddy, P.V.L.; Kim, B.; Lee, S.S.; Pandey, S.K.; Kim, K.H. Benefits and limitations of biochar amendment in agricultural soils: A review. J. Environ. Manag. 2018, 227, 146-154. [CrossRef] [PubMed]

125. Lehmann, J.; Rillig, M.C.; Thies, J.; Masiello, C.A.; Hockaday, W.C.; Crowley, D. Biochar effects on soil biota-A review. Pergamon 2011. [CrossRef]

126. Domene, X. A Critical Analysis of Meso- and Macrofauna Effects Following Biochar Supplementation. In Biochar Application; Elsevier Inc.: Amsterdam, The Netherlands, 2016; pp. 268-292. [CrossRef]

127. Buss, W.; Graham, M.C.; Shepherd, J.G.; Mašek, O. Risks and benefits of marginal biomass-derived biochars for plant growth. Sci. Total Environ. 2016, 569-570, 496-506. [CrossRef]

128. Amaro, A.; Bastos, A.C.; Santos, M.J.G.; Verheijen, F.G.A.; Soares, A.M.V.M.; Loureiro, S. Ecotoxicological assessment of a biochar-based organic N-fertilizer in small-scale terrestrial ecosystem models (STEMs). Appl. Soil Ecol. 2016, 108, 361-370. [CrossRef]

129. Solaiman, Z.M.; Murphy, D.V.; Abbott, L.K. Biochars influence seed germination and early growth of seedlings. Plant Soil 2012, 353, 273-287. [CrossRef]

130. Das, S.K.; Ghosh, G.K.; Avasthe, R. Ecotoxicological responses of weed biochar on seed germination and seedling growth in acidic soil. Environ. Technol. Innov. 2020, 20, 101074. [CrossRef]

131. Stefaniuk, M.; Oleszczuk, P.; Bartmiński, P. Chemical and ecotoxicological evaluation of biochar produced from residues of biogas production. J. Hazard. Mater. 2016, 318, 417-424. [CrossRef]

132. Liao, S.; Pan, B.; Li, H.; Zhang, D.; Xing, B. Detecting free radicals in biochars and determining their ability to inhibit the germination and growth of corn, wheat and rice seedlings. Environ. Sci. Technol. 2014, 48, 8581-8587. [CrossRef]

133. Odinga, E.S.; Waigi, M.G.; Gudda, F.O.; Wang, J.; Yang, B.; Hu, X.; Li, S.; Gao, Y. Occurrence, formation, environmental fate and risks of environmentally persistent free radicals in biochars. Environ. Int. 2020, 134, 105172. [CrossRef]

134. Fang, G.; Liu, C.; Gao, J.; Dionysiou, D.D.; Zhou, D. Manipulation of persistent free radicals in biochar to activate persulfate for contaminant degradation. Environ. Sci. Technol. 2015, 49, 5645-5653. [CrossRef] 